\title{
Air-water fluxes and sources of carbon dioxide in the Delaware Estuary: spatial and seasonal variability
}

\author{
A. Joesoef ${ }^{1}$, W.-J. Huang ${ }^{1, a}$, Y. Gao ${ }^{1}$, and W.-J. Cai ${ }^{1}$ \\ ${ }^{1}$ School of Marine Science and Policy, University of Delaware, Newark, Delaware, USA \\ ${ }^{a}$ present address: Department of Oceanography, National Sun Yat-Sen University, Kaohsiung 804, Taiwan \\ Correspondence to: W.-J. Cai (wcai@udel.edu)
}

Received: 16 June 2015 - Published in Biogeosciences Discuss.: 13 July 2015

Revised: 18 September 2015 - Accepted: 13 October 2015 - Published: 26 October 2015

\begin{abstract}
Distributions of surface water partial pressure of carbon dioxide $\left(p \mathrm{CO}_{2}\right)$ were measured on nine cruises in the Delaware Estuary (USA). The Delaware River was highly supersaturated in $p \mathrm{CO}_{2}$ with respect to the atmosphere during all seasons, while the Delaware Bay was undersaturated in $p \mathrm{CO}_{2}$ during spring and late summer and moderately supersaturated during mid-summer, fall, and winter. While the smaller upper tidal river was a strong $\mathrm{CO}_{2}$ source $\left(27.1 \pm 6.4 \mathrm{~mol}-\mathrm{C} \mathrm{m}^{-2} \mathrm{yr}^{-1}\right)$, the much larger bay was a weak source $\left(1.2 \pm 1.4 \mathrm{~mol}-\mathrm{C} \mathrm{m}^{-2} \mathrm{yr}^{-1}\right)$, the latter of which had a much greater area than the former. In turn, the Delaware Estuary acted as a relatively weak $\mathrm{CO}_{2}$ source $\left(2.4 \pm 4.8 \mathrm{~mol}_{-} \mathrm{C} \mathrm{m}^{-2} \mathrm{yr}^{-1}\right)$, which is in great contrast to many other estuarine systems. Seasonally, $p \mathrm{CO}_{2}$ changes were greatest at low salinities $(0 \leq S<5)$, with $p \mathrm{CO}_{2}$ values in the summer nearly 3 -fold greater than those observed in the spring and fall. Undersaturated $p \mathrm{CO}_{2}$ was observed over the widest salinity range $(7.5 \leq S<30)$ during spring. Near to supersaturated $p \mathrm{CO}_{2}$ was generally observed in mid- to high-salinity waters $(20 \leq S<30)$ except during spring and late summer. Strong seasonal trends in internal estuarine production and consumption of $\mathrm{CO}_{2}$ were observed throughout both the upper tidal river and lower bay. Positive correlations between river-borne and air-water $\mathrm{CO}_{2}$ fluxes in the upper estuary emphasize the significance of river-borne $\mathrm{CO}_{2}$ degassing to overall $\mathrm{CO}_{2}$ fluxes. While river-borne $\mathrm{CO}_{2}$ degassing heavily influenced $\mathrm{CO}_{2}$ dynamics in the upper tidal river, these forces were largely compensated for by internal biological processes within the extensive bay system of the lower estuary.
\end{abstract}

\section{Introduction}

While, globally, the surface area of estuaries is only about $4 \%$ that of continental shelves, recent studies have concluded that the carbon dioxide $\left(\mathrm{CO}_{2}\right)$ degassing flux from estuarine waters is as large as the $\mathrm{CO}_{2}$ uptake by the continental shelf (Borges, 2005; Borges et al., 2005; Cai et al., 2006; Chen and Borges, 2009; Cai, 2011). Global estuarine waters are estimated to emit $0.10-0.45 \mathrm{PgC} \mathrm{yr}^{-1}$, while continental shelves take up 0.20-0.40 $\mathrm{Pg} \mathrm{C} \mathrm{yr}^{-1}$ (Borges, 2005; Borges et al., 2005; Cai, 2011; Chen et al., 2013; Regnier et al., 2013; Laruelle et al., 2015). Such large estuarine $\mathrm{CO}_{2}$ degassing suggests that much of the terrestrial organic carbon, including that from coastal wetlands, is respired to $\mathrm{CO}_{2}$ during transport through the estuarine zone, though the relative importance of river-supplied $\mathrm{CO}_{2}$ and organic carbon versus those from the coastal wetlands is debatable (Borges and Abril, 2011; Cai, 2011). In turn, estuarine waters are a major source of $\mathrm{CO}_{2}$ to the atmosphere, with partial pressures of $\mathrm{CO}_{2}\left(p \mathrm{CO}_{2}\right)$ ranging from 350 to $10000 \mu \mathrm{atm}$ and air-water $\mathrm{CO}_{2}$ fluxes ranging from -5 to $80 \mathrm{~mol} \mathrm{C} \mathrm{m}^{-2} \mathrm{yr}^{-1}$ (Raymond et al., 1997; Cai and Wang, 1998; Frankignoulle et al., 1998; Borges, 2005; Borges et al., 2006; Borges and Abril, 2011; Cai, 2011).

There is rising concern that global estuarine $\mathrm{CO}_{2}$ degassing flux may be overestimated (Cai, 2011). Although substantial progress has been achieved over the past decade (Borges and Abril, 2011; Chen et al., 2013; and references therein), our knowledge of $\mathrm{CO}_{2}$ degassing fluxes and their controlling processes in estuaries remains insufficient. Globally, the majority of past estuarine $\mathrm{CO}_{2}$ studies have been conducted on small estuarine systems, which typically have 
high $p \mathrm{CO}_{2}$. (Chen and Borges, 2009; Cai, 2011; Borges and Abril, 2011). Specifically, in the US east coast, high $p \mathrm{CO}_{2}$ has been found in estuaries along the southeastern (Cai and Wang, 1998; Jiang et al., 2008a) and northeastern (Salisbury et al., 2008; Hunt et al., 2010) coastal regions. While high $p \mathrm{CO}_{2}$ has also been found in small estuaries along the US mid-Atlantic coast (Raymond et al., 1997; Raymond et al., 2000), only a few estuarine $\mathrm{CO}_{2}$ studies have been conducted in this region, such as Crosswell et al. (2012) in the Neuse River, NC; Raymond et al. (1997) in Hudson River, NY; and Raymond et al. (2000) in the York River, VA. Thus, there is limited research on $\mathrm{CO}_{2}$ dynamics in large estuaries or bay systems with long freshwater residence times in the US mid-Atlantic coast (most notably the Chesapeake and Delaware estuaries). Presumably, these large estuaries have lower $p \mathrm{CO}_{2}$ than small estuaries or bay systems with rapid freshwater transit times (Borges and Abril, 2011; Cai, 2011). Except for a few recent studies and the pioneering work of Sharp and Culberson, over the past 30 years there have been few inorganic carbon studies in the Delaware Estuary (Culberson, 1988; Sharp et al., 2009). Air-water $\mathrm{CO}_{2}$ fluxes, total DIC fluxes, and ongoing evaluations of water acidification have not been consistently (via annual and seasonal surveys) studied. Overall, there is a lack of data and a pressing need to synthesize and expand global research to larger estuaries. Furthermore, of past estuarine $\mathrm{CO}_{2}$ studies, many lack spatial and seasonal coverage of surface water $p \mathrm{CO}_{2}$ and air-water $\mathrm{CO}_{2}$ fluxes, making flux estimates highly uncertain.

The Delaware Estuary is divided into an upper $100 \mathrm{~km}$ long tidal Delaware River and lower Delaware Bay (Fig. 1; Sharp, 2010). With a relatively simple hydrology, the Delaware Estuary is fairly easy to characterize, and because of this it has served as a model estuary for biogeochemical studies (Cifuentes et al., 1988; Sharp et al., 2009). The tidal freshwater portion of the Delaware River flows from the head of the tide near Trenton, NJ, through the greater Philadelphia area, the sixth largest municipal region of the US, before passing into the saline Delaware Bay (Fig. 1; Sharp et al., 2009; Sharp, 2010). In turn, the upper Delaware River is heavily influenced by major industrial activity and continuously responding to a rapidly changing environment. For example, in the mid-20th century, the urban river of the Delaware Estuary suffered from severe hypoxia, with average summer dissolved oxygen (DO) concentrations near zero (Sharp, 2010). Fortunately, the implementation of the Clean Water Act (CWA) in the early 1970s helped promote efforts to improve water quality conditions in the Delaware River. With major upgrades to large sewage treatment plants, DO concentrations since the early 1990s have consistently been above the CWA standard of $3.5 \mathrm{mg} \mathrm{L}^{-1}\left(\sim 219 \mu \mathrm{mol} \mathrm{L}^{-1}\right.$; Sharp, 2010). Nonetheless, high $p \mathrm{CO}_{2}$ is still expected to be associated with strong respiratory $\mathrm{O}_{2}$ consumption in the upper estuary. In contrast, the Delaware Bay is a large shallow embayment surrounded by salt marshes with minimal industrial or municipal inputs (Cifuentes et al., 1988). Thus,

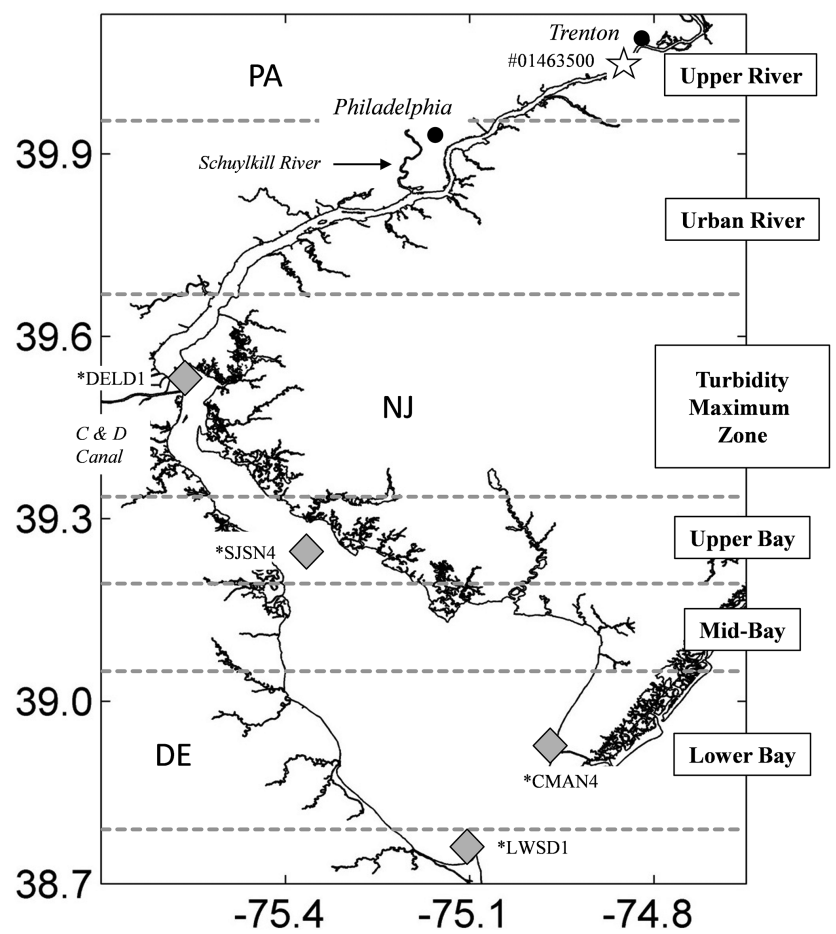

Figure 1. Map of the Delaware Estuary divided into six zones from the head of the tide in Trenton, NJ to the mouth of the bay as defined in Sharp et al. (2009). The gray diamonds indicate the position of four NOAA buoys (LWSD1, CMAN4, SJSN4, and DELD1). The white star shows the location of the USGS gauging station (\#01463500).

the Delaware Estuary is governed by the dynamic interaction between a river-dominated upper estuary and an oceandominated lower bay. This feature, typical for other large estuaries and, depending on river flow and geomorphology, smaller estuarine systems as well, provides us the opportunity to examine how contrasting geographical settings, physical mixing processes, and ecosystem metabolism in an extensive bay system can affect $\mathrm{CO}_{2}$ gas exchange.

In this paper, we report the first seasonal distribution of $p \mathrm{CO}_{2}$ and air-water $\mathrm{CO}_{2}$ flux in the Delaware Estuary, which was surveyed nine times via various day- to week-long surveys from 2013 through 2014. We further assess the temperature and biological effects on $p \mathrm{CO}_{2}$ distributions as well as the overall contribution of internal versus riverine sources on $\mathrm{CO}_{2}$ inputs to the estuarine system. Finally, we present a summarized $p \mathrm{CO}_{2}$ distribution over the study area and provide a conceptual model to illustrate the control mechanisms on surface water $\mathrm{CO}_{2}$ dynamics in the Delaware Estuary. 


\section{Methods}

\subsection{Field measurements}

The Delaware Estuary was surveyed on nine cruises: 8 10 June 2013, 8-15 August 2013, 17 October 2013, 1722 November 2013, 23-24 March 2014, 3 July 2014, 27 August-1 September 2014, 30 October-2 November 2014, and 5 December 2014. Distributions of $p \mathrm{CO}_{2}$, dissolved inorganic carbon (DIC), total alkalinity (TA), and $\mathrm{pH}$ were measured from the mouth of the bay to the near-zero salinity of the estuary in five of the nine cruises. During the August and October 2013 cruises, only surface water $p \mathrm{CO}_{2}$ was measured.

To monitor levels of $p \mathrm{CO}_{2}$, surface water was directly pumped from 1 to $2 \mathrm{~m}$ below the sea level through an underway $p \mathrm{CO}_{2}$ analyzer (AS-P2, Apollo Scitech) installed in the shipboard laboratory (Huang et al., 2015). Surface water flowed into a $1 \mathrm{~L}$ volume shower head equilibrator at a minimum rate of $1.7 \mathrm{~L} \mathrm{~min}^{-1}$ to facilitate rapid gas exchange. A specifically designed water-drain system is attached to the equilibrator to insure that the pressure inside and outside remains balanced (Jiang et al., 2008b). The equilibrated gas was pumped through a water trap (Peltier cooler), which removed most of the water vapor, and then into a drying tube packed with magnesium perchlorate $\left(\mathrm{Mg}\left(\mathrm{ClO}_{4}\right)_{2}\right)$ or Nafion tubing. Surface water $\mathrm{CO}_{2}$ (mole fraction of dry air $\left(x \mathrm{CO}_{2}\right)$ ) was measured approximately every $1.5 \mathrm{~min}$ using an underway flow-through system equipped with a non-dispersive infrared (NDIR) gas analyzer (Li-Cor, model LI-7000, Lincoln, NE, USA). The LI-7000 was calibrated, every 3-6h, against three or four $\mathrm{CO}_{2}$ gas standards (151.5, 395.4, 982.6, and $1969 \mathrm{ppm} \mathrm{CO}_{2}$ in air) referenced against standards traceable to those of the National Institute of Standards and Technology (NIST). Atmospheric $x \mathrm{CO}_{2}$ was measured every 3$6 \mathrm{~h}$ using the same $\mathrm{CO}_{2}$ system. In order to avoid contamination from the ship's stack gases or other possible sources of air pollution, the inlet of the atmospheric $\mathrm{CO}_{2}$ pipe was installed on the highest platform in the front of the ship. An onboard Sea-Bird thermosalinograph (SBE-45) measured surface water temperature and salinity. To calculate surface water and atmospheric $p \mathrm{CO}_{2}$ values, all $x \mathrm{CO}_{2}$ measurements were corrected to $100 \%$ saturation of water vapor pressure and the in situ surface water temperature (Dickson et al., 2007).

DIC and TA water samples were collected throughout the salinity gradient. Multiple samples were taken at near-zero salinity and at the mouth of the bay to obtain river and ocean end-member values. Samples for DIC and TA measurements were filtered through a cellulose acetate filter $(0.45 \mu \mathrm{m})$ into $250 \mathrm{~mL}$ borosilicate bottles and then fixed with $100 \mu \mathrm{L}$ of saturated mercury bichloride solution (Cai and Wang, 1998; Jiang et al., 2008a). When collecting water, all bottles were overflowed for at least twice its volume to minimize contact with the atmosphere. Afterwards, sample bottles were kept at 4 to $10{ }^{\circ} \mathrm{C}$ for future analysis. DIC was determined by acidifying $0.5-1.0 \mathrm{~mL}$ samples with phosphoric acid. The extracted $\mathrm{CO}_{2}$ gas was subsequently quantified via an infrared gas analyzer (AS-C3 Apollo Scitech). TA was measured by Gran titration (Gran, 1952) using the open-cell method with a semi-automatic titration system (AS-ALK2, Apollo Scitech; Cai et al., 2010a; Huang et al., 2012). Both DIC and TA measurements were calibrated against certified reference material (CRM, provided by A. G. Dickson from Scripps Institution of Oceanography) at a precision level of about $\pm 2 \mu \mathrm{mol} \mathrm{kg}-1$ (Huang et al., 2012).

\subsection{Air-water $\mathrm{CO}_{2}$ flux estimation}

In this study, air-water $\mathrm{CO}_{2}$ fluxes $\left(F, \mathrm{mmol} \mathrm{m}^{-2} \mathrm{~d}^{-1}\right)$ at pixel $i$ of a 0.01 longitude $\times 0.01$ latitude grid were calculated as follows:

$F_{i}=k_{i} \cdot K_{o i} \cdot\left(p \mathrm{CO}_{2(\text { water }) i}-p \mathrm{CO}_{2(\text { air }) i}\right)$,

where $k_{i}\left(\mathrm{~cm} \mathrm{~h}^{-1}\right)$ is the gas transfer velocity of $\mathrm{CO}_{2} ; K_{o i}$ is the solubility coefficient of $\mathrm{CO}_{2}\left(\mathrm{~mol} \mathrm{~L}^{-1} \mathrm{~atm}^{-1}\right)$, which can be calculated from in situ temperature and salinity (Weiss, 1974); and $p \mathrm{CO}_{2 \text { (water) } i}$ and $p \mathrm{CO}_{2 \text { (air) } i}$ ( $\mu$ atm) are the partial pressure of $\mathrm{CO}_{2}$ in the water and the air, respectively. The mean atmospheric $\left[x \mathrm{CO}_{2}\right]$ during each cruise and the sea surface temperature, salinity, and pressure were used to calculate the $p \mathrm{CO}_{2 \text { (air) } i}$. A positive $F$ value indicates $\mathrm{CO}_{2}$ transfer from water to the atmosphere.

Generally, two main issues arise when trying to accurately determine air-water $\mathrm{CO}_{2}$ fluxes in coastal waters: (1) how to accurately represent surface turbulence and (2) obtaining spatial and temporal heterogeneity of $p \mathrm{CO}_{2}$ distributions. One of the greatest uncertainties when calculating air-water $\mathrm{CO}_{2}$ fluxes is estimating gas transfer velocities (Wanninkhof et al., 2009). While gas transfer velocities primarily depend on wind regime in the open ocean, in coastal and shallower estuaries it is probably more complicated as other factors such as tidal currents, bottom stress, wave slope, turbidity, surface films, and fetch limitation can also influence gas exchange rates (Raymond and Cole, 2001; Borges et al., 2004; Zappa et al., 2007; Jiang et al., 2008a; Abril et al., 2009). Unfortunately, because there have not been many studies on gas transfer velocities in estuaries, we relied on wind speed dependence to estimate gas exchange rates. Moreover, limited research has been conducted at wind speeds less than $4 \mathrm{~m} \mathrm{~s}^{-1}$. In turn, quadratic relationships that estimate $k$ often extrapolate to zero at low wind speeds (Wanninkhof et al., 2009). Increasing evidence suggests that $k$ does not approach zero at low wind speeds but rather asymptotes to a finite value due to various external factors such as buoyancy effects, chemical enhancements, and physical mixing processes (McGillis et al., 2001; McGillis et al., 2004; Wanninkhof et al., 2009). To avoid gas transfer velocities of zero in river and inland waters where wind speeds are typically low, we adopted the gas transfer relationship as proposed by 
Wanninkhof et al. (2009):

$k_{660}=3+0.1 \cdot U_{10}+0.064 \cdot U_{10}^{2}+0.011 \cdot U_{10}^{3}$,

where $k_{660}$ is the gas transfer velocity at the Schmidt number of 660 , which can be calculated from in situ sea surface temperature (Wanninkhof, 1992), and $U_{10}$ is the wind speed at $10 \mathrm{~m}$ above the water surface. Another challenge to accurately determining air-water $\mathrm{CO}_{2}$ fluxes is obtaining reliable spatial and temporal $p \mathrm{CO}_{2}$ distributions. Unfortunately, while seasonal distributions of $p \mathrm{CO}_{2}$ were measured from the mouth of the bay to the near-zero salinity of the estuary (north to south), our lack of cross-bay transects (east to west) limits our knowledge of $\mathrm{CO}_{2}$ dynamics in shallow water regions of the estuary. Thus, there is a pressing need to conduct more research near these shallow water boundaries.

In addition, because the relationship between $k$ and mean wind speeds is nonlinear, temporal distributions of wind speeds influence gas transfer velocities (Wanninkhof, 1992; Wanninkhof et al., 2002). To accurately determine the effect of variability of winds over a month, Wanninkhof (1992) introduced the nonlinearity coefficient of the wind speeds $\left(C_{2}\right)$, which is calculated as follows (Wanninkhof et al., 2002; Jiang et al., 2008b):

$C_{2}=\left(\frac{1}{n} \sum_{j=1}^{n} U_{j}^{2}\right) / U_{\text {mean }}^{2}$,

where $C_{2}$ is the nonlinearity coefficient for quadratic terms of gas transfer relationships, $U_{j}$ is the high-frequency wind speed collected at the buoys, $U_{\text {mean }}$ is the monthly mean wind speed, and $n$ is the total number of available wind speeds during that month. We used high-frequency wind speed data (measured every $6 \mathrm{~min}$ ) obtained from four National Oceanic and Atmospheric Administration (NOAA) buoys (LWSD1, CMAN4, SJSN4, and DELD1) to calculate the nonlinearity coefficients at each buoy and extrapolate them to the entire estuary. Using the calculated nonlinearity coefficients, gas transfer relationships were corrected to obtain the most accurate relationship between gas transfer velocities and wind speeds during each month.

In order to calculate area-averaged $\mathrm{CO}_{2}$ flux throughout the Delaware Estuary, the system was divided into five geographic zones as defined by Sharp et al. (2009). However, due to rapid change in $p \mathrm{CO}_{2}$ values across the mid-bay, this region was split into an upper and mid-bay zone to allow for a more robust comparison of $p \mathrm{CO}_{2}$ and $\mathrm{CO}_{2}$ fluxes throughout the system (Fig. 1). Surface water $p \mathrm{CO}_{2}$, temperature, salinity, wind speed, and pressure were interpolated onto a $0.01 \times 0.01$ grid. Following the same method as presented in Jiang et al. (2008b), flux $F_{i}$ at each pixel was calculated:

$S_{i}=\frac{\Delta \mathrm{Lon}}{2 \pi} \cdot 2 \cdot \pi \cdot R^{2} \cdot\left[\sin \left(\mathrm{Lat}_{i}+\frac{1}{2} \Delta \mathrm{Lat}\right)-\sin \left(\mathrm{Lat}_{i}-\frac{1}{2} \Delta \mathrm{Lat}\right)\right]$,

where $S_{i}$ is the total area surrounding pixel $i, \Delta$ Lon and $\Delta$ Lat are the longitude and latitude intervals of the grid, respectively, Lat $i$ is the latitude at pixel $i$, and $R$ is the radius of the earth. The area-averaged $\mathrm{CO}_{2}$ flux was calculated as follows (Jiang et al., 2008b):

$F_{\text {area-averaged }}=\frac{1}{S_{1}+S_{2}+\ldots S_{n}} \cdot \sum_{i=1}^{n} F_{i} \cdot S_{i}$.

Because there is no precise method to account for the uncertainties of air-water $\mathrm{CO}_{2}$ fluxes, we followed the same approach as described in Jiang et al. (2008b). Atmospheric measurements for each cruise and gas transfer velocities of Wanninkhof et al. (2009) and Wanninkhof (2014) were used to estimate standard deviations of the atmospheric $\mathrm{CO}_{2}$ and $\mathrm{CO}_{2}$ flux, respectively.

\subsection{Temperature-normalized $p \mathrm{CO}_{2}$ estimation}

Temperature changes are important as they influence surface water $p \mathrm{CO}_{2}$ by governing the thermodynamic equilibrium of the inorganic carbon system (Takahashi et al., 1993). If only controlled by temperature change and no other physical (mixing) or biogeochemical changes, $p \mathrm{CO}_{2}$ in surface seawater would double for every $16^{\circ} \mathrm{C}$ increase $\left(\partial \ln p \mathrm{CO}_{2} / \partial T=0.0423^{\circ} \mathrm{C}\right.$; Takahashi et al., 1993). The temperature constant above determined by Takahashi et al. (1993) works well for open-ocean waters with salinities between 34 and 36 as physical mixing with freshwater is generally minor. After temperature normalization, one may attribute the remaining $p \mathrm{CO}_{2}$ change to non-thermal processes (mostly biological activity but possibly also mixing processes). However, in coastal oceans mixing is often serious and influences the interpretations of observed temperature dependences. For example, Jiang et al. (2008a) found that values of $\left(\partial \ln p \mathrm{CO}_{2} / \partial T\right)$ in river- and marine-dominated estuaries were less (about $0.027-0.042{ }^{\circ} \mathrm{C}^{-1}$ ) than that determined by Takahashi et al. (1993). We suggest that a thermodynamic prediction for estuarine water should be used for such comparisons (Bai et al., 2015). We first derived temperature constants for a general estuarine system using the Excel macro CO2SYS (Pierrot, 2006) and inorganic carbon dissociation constants from Millero et al. (2006) for estuarine waters $(S<30)$ and from Mehrbach et al. (1973) refit by Dickson and Millero (1987) for high-salinity waters $(S>30)$. Based on data collected over the past two years, river and ocean end-members of TA ( 900 and $2300 \mu \mathrm{mol} \mathrm{kg}^{-1}$, respectively) and of DIC (960 and $2000 \mu \mathrm{mol} \mathrm{kg}{ }^{-1}$, respectively) were used. Calculated $p \mathrm{CO}_{2}$ varied among different temperatures, from 5 to $30^{\circ} \mathrm{C}$, with the largest difference in low salinities (0 to 5 ; Fig. 2). In turn, when binning salinities to intervals of 5 units, the greatest variability in temperature constants was observed in salinities $0-5$ and 5-10 (Table 1). Averaged values of $\left(\partial \ln p \mathrm{CO}_{2} / \partial T\right)$ for salinity intervals between 0 and 35 ranged from 0.0332 to $0.0420^{\circ} \mathrm{C}^{-1}$ (Table 1). Similar to the results found in Jiang et al. (2008a), temperature-derived constants were lower than the isochemical seawater constant $0.0423^{\circ} \mathrm{C}^{-1}$ determined by Takahashi 
Table 1. Averaged temperature coefficients $\left(\partial \ln p \mathrm{CO}_{2} / \partial T\right)$ for each salinity bin. Simulated surface water $p \mathrm{CO}_{2}$ values at varying salinities were computed using river and ocean end-member TA and DIC values of 900 and $960 \mu \mathrm{mol} \mathrm{kg}^{-1}$ and 2300 and 2000, respectively.

\begin{tabular}{lr}
\hline Salinity & Coefficient \\
\hline $0-5$ & 0.0332 \\
$5-10$ & 0.0382 \\
$10-15$ & 0.0411 \\
$15-20$ & 0.0417 \\
$20-25$ & 0.0417 \\
$25-30$ & 0.0415 \\
$30-35$ & 0.0420 \\
\hline
\end{tabular}

et al. (1993). Thus, knowing the extensively complex nature of estuarine systems, it is important to note that derived variances in temperature-normalized $p \mathrm{CO}_{2}$ provide only a relatively simple analysis of seasonal $p \mathrm{CO}_{2}$ fluctuations due to temperature and biological processes as derived variances in temperature-normalized $\mathrm{pCO} 2$ neglect the impact that various physical processes, turbulent forces, and tidal mixing scenarios have on $p \mathrm{CO}_{2}$ dynamics.

Using a similar approach to that in Takahashi et al. (2002), we also attempted to separate the temperature effect from other non-thermal effects on seasonal $p \mathrm{CO}_{2}$ change. We first normalized the $\mathrm{pCO}_{2}$ at in situ temperature to the 10-year (2004-2014) annual mean temperature of $13.3^{\circ} \mathrm{C}$ via the following (Takahashi et al., 2002):

$\left(p \mathrm{CO}_{2 \text { obs }}\right.$ at $\left.T_{\text {mean }}\right)=\left(p \mathrm{CO}_{2}\right)_{\text {obs }} \cdot \exp \left[C_{\mathrm{s}}\left(T_{\text {mean }}-T_{\text {obs }}\right)\right]$,

where $T$ is temperature $\left({ }^{\circ} \mathrm{C}\right), C_{\mathrm{s}}$ is the averaged $\left(\partial \ln p \mathrm{CO}_{2} / \partial T\right)$ value for the salinity interval, and subscripts "mean" and "obs" indicate the annual mean and observed values. Through this approach, we attributed any differences between calculated and observed $p \mathrm{CO}_{2}$ values to be the result of biological activity and/or physical mixing processes (non-thermal). Because salinity gradients down the estuary vary greatly depending on the season, river discharge, tidal cycle, precipitation, and other circulation processes, salinitybinned climatologies can provide crucial insight into and a different perspective of the various physical and biological controls behind observed $p \mathrm{CO}_{2}$ distributions that geographic boundaries may not. In turn, $p \mathrm{CO}_{2}$ values from each survey were constructed into salinity-binned climatologies (intervals of 5 salinity units from 0 to 30) to better isolate and interpret the thermal versus non-thermal effects on seasonal $p \mathrm{CO}_{2}$ fluctuations. Observed $p \mathrm{CO}_{2}$ values during months with no surveys were estimated by linearly regressing data from adjacent months with sample measurements. In contrast, to best analyze the effect of temperature changes on observed $p \mathrm{CO}_{2}$ values, annual mean $p \mathrm{CO}_{2}$ values across each salinity interval were used in conjunction with the mean and observed temperatures via the following equation (Takahashi

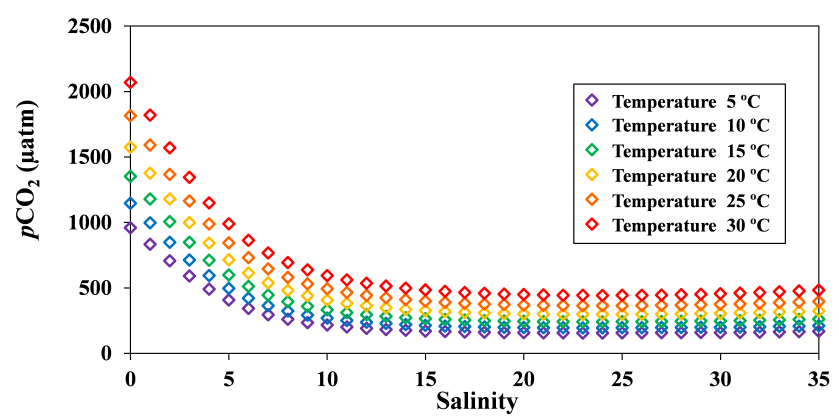

Figure 2. Simulated surface water $p \mathrm{CO}_{2}$ against salinity grouped by temperature bins. Surface water $p \mathrm{CO}_{2}$ values were calculated using river and ocean end-member TA and DIC values of 900 and $960 \mu \mathrm{mol} \mathrm{kg}{ }^{-1}$ and 2300 and $2000 \mu \mathrm{mol} \mathrm{kg}{ }^{-1}$, respectively.

et al., 2002):

$\left(p \mathrm{CO}_{2 \text { mean }}\right.$ at $\left.T_{\text {obs }}\right)=\left(p \mathrm{CO}_{2}\right)_{\text {mean }} \cdot \exp \left[C_{\mathrm{s}}\left(T_{\text {obs }}-T_{\text {mean }}\right)\right]$.

Using this method, we attributed any differences between calculated mean versus observed $p \mathrm{CO}_{2}$ values as a result of seasonal temperature changes. To remove the temperature effect from observed in situ $p \mathrm{CO}_{2}$, the observed $p \mathrm{CO}_{2}$ values were normalized to a constant temperature of $13.3^{\circ} \mathrm{C}$, which was the 10-year annual mean water temperature measured in the Delaware Estuary from 2004 to 2014.

\subsection{Estuarine and river $\mathrm{CO}_{2}$ contributions}

Due to various $\mathrm{CO}_{2}$ sources such as the degradation of organic matter, discharge of sewage effluents, soil-induced respiration, freshwater runoff, and addition of humic substances, river water flowing into estuarine systems is typically supersaturated in $\mathrm{CO}_{2}$ with respect to the atmosphere (Raymond et al., 2000; Abril and Borges, 2004; Borges et al., 2006). To investigate the influence of river-borne $\mathrm{CO}_{2}$ input to overall air-water $\mathrm{CO}_{2}$ fluxes, we used similar methods to those performed in Jiang et al. (2008a). In situ DIC and TA measurements were coupled using the Excel macro CO2SYS (Pierrot, 2006) and inorganic carbon dissociation constants from Millero et al. (2006) for estuarine waters to calculate dissolved $\mathrm{CO}_{2}$ concentrations. We first estimated the contribution of the ocean end-member to the estuarine DIC alone as follows (Jiang et al., 2008a):

$\mathrm{DIC}_{\text {mixing w/o }}=\frac{S_{i}}{S_{\text {ocean }}} \cdot \mathrm{DIC}_{\text {ocean }}$,

where $\mathrm{DIC}_{\text {mixing w/o }}$ is the DIC concentration after the ocean end-member is diluted by fresh water with zero DIC and $S_{i}$ and $S_{\text {ocean }}$ are in situ and ocean end-member salinities, respectively (Fig. 3a). When DIC inputs from both the river and the ocean end-members were considered, estuarine DIC was estimated using a two-end-member mixing model as fol- 
lows (Jiang et al., 2008a):

$\mathrm{DIC}_{\text {mixing } \mathrm{w} / \mathrm{R}}=\frac{S_{i}}{S_{\text {ocean }}} \cdot \mathrm{DIC}_{\text {ocean }}+\left(1-\frac{S_{i}}{S_{\text {ocean }}}\right) \cdot \mathrm{DIC}_{\text {river }}$,

where $\mathrm{DIC}_{\text {mixing }} \mathrm{w} / \mathrm{R}$ is the $\mathrm{DIC}$ concentration after mixing of river and ocean end-members and $\mathrm{DIC}_{\text {river }}$ is the river endmember (Fig. 3a). With much of the DIC pool dominated by carbonate and bicarbonate ions, Sharp et al. (2009) observed small seasonal influences on DIC concentrations due to temperature affects and biological activity. They suggest that the majority of variability in DIC in the upper tidal river of the Delaware Estuary is due to the combined interaction of varying precipitation rates and prior meteorological conditions. This is expected as river DIC and TA are largely a dilution of weathering production by rain (Cai et al., 2008). However, at higher salinities, any drawdown of DIC relative to salinity is small since less than $1 \%$ of the DIC pool exists as $p \mathrm{CO}_{2}$ (Sharp et al., 2009). Thus, while total DIC concentrations illustrate some fluctuations in biological activity (which occurred mostly at the highly productive mid-bay), it is an integrated measurement of freshwater and seawater mixing (Sharp et al., 2009). $\mathrm{TA}_{\text {mixing w/o }}$ and $\mathrm{TA}_{\text {mixing w/R }}$ were also estimated using similar equations by replacing DIC with TA (Fig. 3b). Because $\mathrm{CO}_{2}$ concentrations do not change linearly during mixing, they were estimated using corresponding DIC and TA mixing values (Fig. 3c; Jiang et al., 2008a). Moreover, since $\mathrm{CO}_{2}$ concentrations fluctuate with temperature change, the 10-year (2004-2014) annual mean temperature of $13.3^{\circ} \mathrm{C}$ was used in this work. Thus, the $\mathrm{CO}_{2}$ contribution due to river input $\left(\Delta\left[\mathrm{CO}_{2}\right]_{\text {riv }}\right)$ was estimated as follows:

$\left[\mathrm{CO}_{2}\right]_{\text {riv }}=\left[\mathrm{CO}_{2}\right]_{\text {mixing } \mathrm{w} / \mathrm{R}}-\left[\mathrm{CO}_{2}\right]_{\text {mixing w/o }}$.

Calculated river $\mathrm{CO}_{2}$ inputs $\left(\left[\mathrm{CO}_{2}\right]_{\text {riv }}\right)$ and combined river discharges from the Schuylkill and Delaware rivers for each month were used to compute river-borne $\mathrm{CO}_{2}$ fluxes in the upper tidal river.

To further investigate the influence of $\mathrm{CO}_{2}$ inputs from the river (external) versus production from within the estuary (internal), we used a similar but modified method as performed in Jiang et al. (2008a). The $\mathrm{CO}_{2}$ contribution from within the estuarine zone $\left(\left[\mathrm{CO}_{2}\right]_{\text {est }}\right)$ was estimated as follows:

$\left[\mathrm{CO}_{2}\right]_{\mathrm{est}}=\left[\mathrm{CO}_{2}\right]_{i}-\left[\mathrm{CO}_{2}\right]_{\text {mixing w/R }}+\left(\tau_{i} \cdot F_{i}\right)$,

where $\left[\mathrm{CO}_{2}\right]_{i}$ is the in situ $\mathrm{CO}_{2}$ concentration, $\tau_{i}$ is the flushing time, and $F_{i}$ is the air-water $\mathrm{CO}_{2}$ flux. Specifically, $\left[\mathrm{CO}_{2}\right]_{i}$ was calculated using in situ DIC and TA concentrations and $\tau_{i}$ was estimated using river discharge rates and volume of each region (Table 3; Sheldon and Merryl, 2002). Surveys that did not contain sufficient river end-member DIC and TA measurements were excluded. Alternatively, Eq. (11) suggests that integrated $\mathrm{CO}_{2}$ degassing $\left(\tau_{i} \times F_{i}\right)$ is supported by the deficit or excess $\mathrm{CO}_{2}$ concentration $\left(\left[\mathrm{CO}_{2}\right]_{\text {mixing }} \mathrm{w}^{-}\right.$ $\left[\mathrm{CO}_{2}\right]_{i}$ ) plus the internal estuarine $\mathrm{CO}_{2}$ production or consumption $\left(\left[\mathrm{CO}_{2}\right]_{\text {est }}\right)$ exhibited across each region.
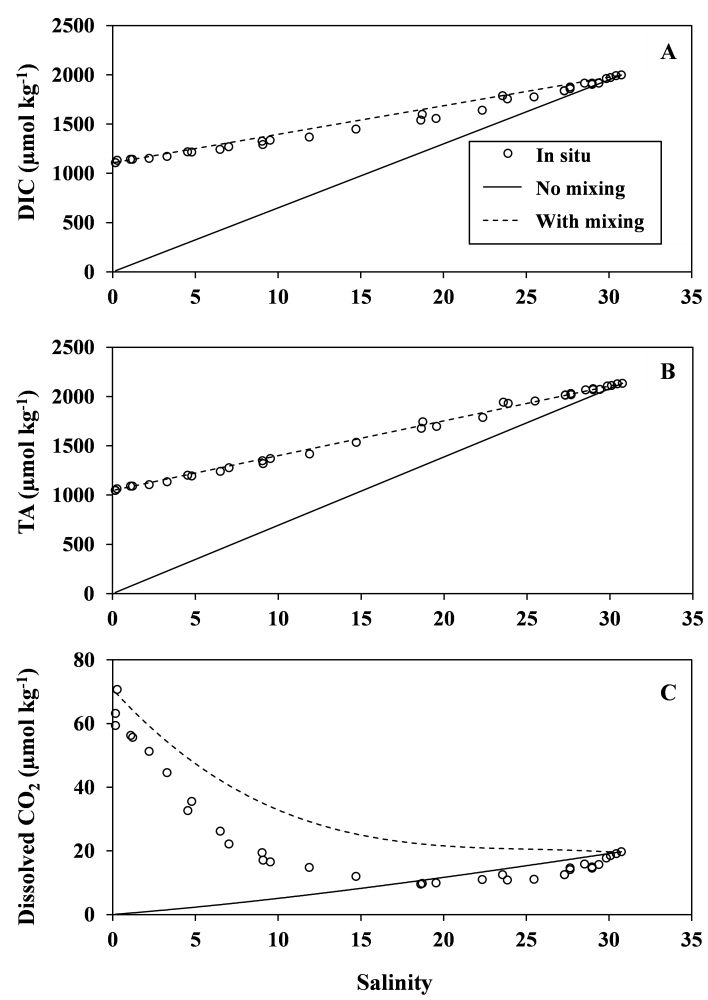

Figure 3. Concentrations of (a) DIC, (b) TA, and (c) dissolved $\mathrm{CO}_{2}$ in the Delaware Estuary during March 2014. Open circles represent in situ concentrations. Solid lines represent values after the ocean end-member is diluted by freshwater with a concentration of zero units. Dotted lines represent concentration after mixing of river and ocean end-members. CO2SYS was used to calculate $p \mathrm{CO}_{2}$ from measured DIC and TA.

\section{Results}

\subsection{Hydrographic conditions}

Measured surface water temperatures and river discharge during each cruise were compared with the 10-year (20042014) and 30-year (1980-2014) monthly averages for surface water temperatures and Delaware River discharge rates, respectively. Water temperatures were slightly cooler than the 10-year average during March 2014, June 2013, and July 2014, while water temperatures during the rest of the cruises were slightly warmer (Fig. 4a; USGS gauge 01463500). Discharge conditions during each survey were compared with the 30-year average discharges from 1980 to 2014 (Fig. 4b; USGS gauge 01463500). The Delaware River discharge was greatest during March 2014 and June 2013. Discharges were smallest during August 2014, October 2013, November 2013, and November 2014. Of the four low-flow months, all of them except for August 2014 had discharge rates less than 1 standard deviation of the 30 -year average.

The surface water salinity distributions confirm the various river discharge conditions recorded throughout each sur- 

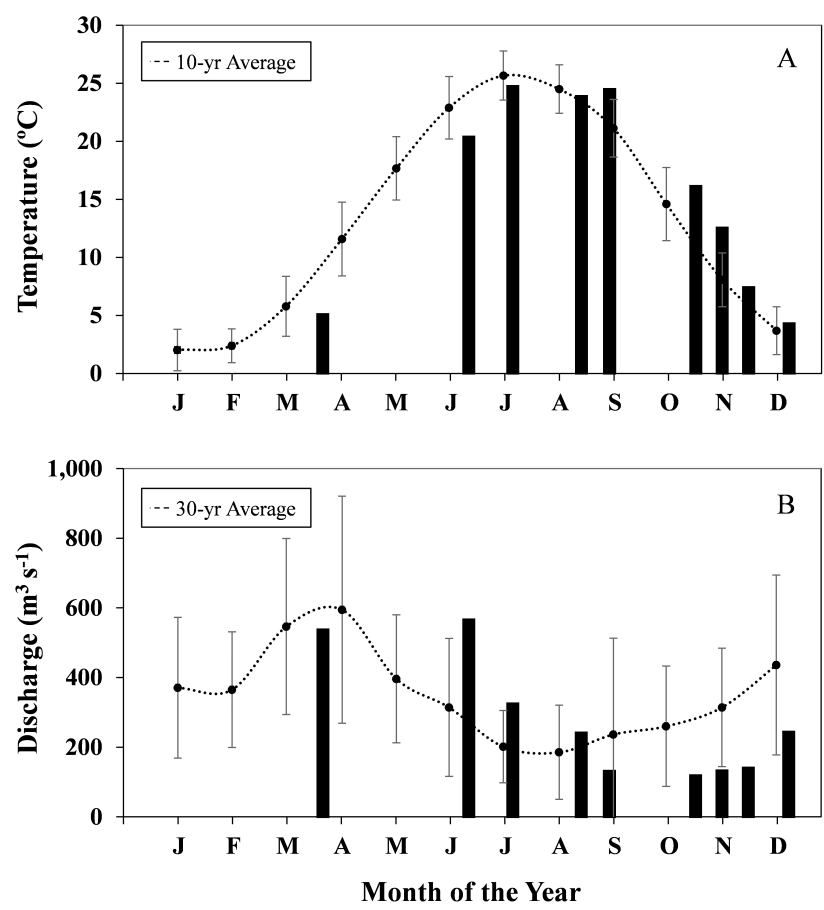

Figure 4. (a) Surface water temperatures and (b) Delaware River discharge rates recorded in the Delaware Estuary during each sampling month. Error bars represent standard deviations of the 10-year (2004-2014) and 30-year (1980-2014) monthly averages for surface water temperatures and Delaware River discharge rates, respectively.

vey (Fig. 5a-i). Salinity $<1.0$ was reached on six of the nine cruises (Fig. 5a, b, c, e, g, and h). The July 2014, August 2013, and October 2013 cruises only transected as far north as the Chesapeake and Delaware Canal (about $39.55^{\circ} \mathrm{N}$; Fig. 1). Salinity < 1.0 (a minimum of 0.98 ) was only observed during the July 2014 excursion, which had the highest river discharge of the three partial surveys (Fig. 5c). Generally, high-salinity waters (25-32.5) were observed in the lower bay and salinities around 20 to 25 in the mid-bay. The upper bay had a much broader scale ranging from salinities of 10 to 20 and during the high-flow months of March 2014 and June 2013 salinities $<10$ were observed (Fig. 5a and b). Salinities did not reach less than 0.25 in the turbidity maximum zone. Salinity distributions in the urban river were limited due to the lack of surveys conducted in this region.

\subsection{Surface water $p \mathrm{CO}_{2}$}

Generally, surface water $p \mathrm{CO}_{2}$ in the Delaware Estuary increased from the ocean to the river end-member, with $p \mathrm{CO}_{2}$ values ranging from about 150 to over $4000 \mu$ atm (Fig. 6a-i). Moreover, $p \mathrm{CO}_{2}$ exhibited strong seasonal variations across both river and bay portions. The most pronounced shifts in surface water $p \mathrm{CO}_{2}$ were observed within the lower urban river and turbidity maximum river zones of the Delaware
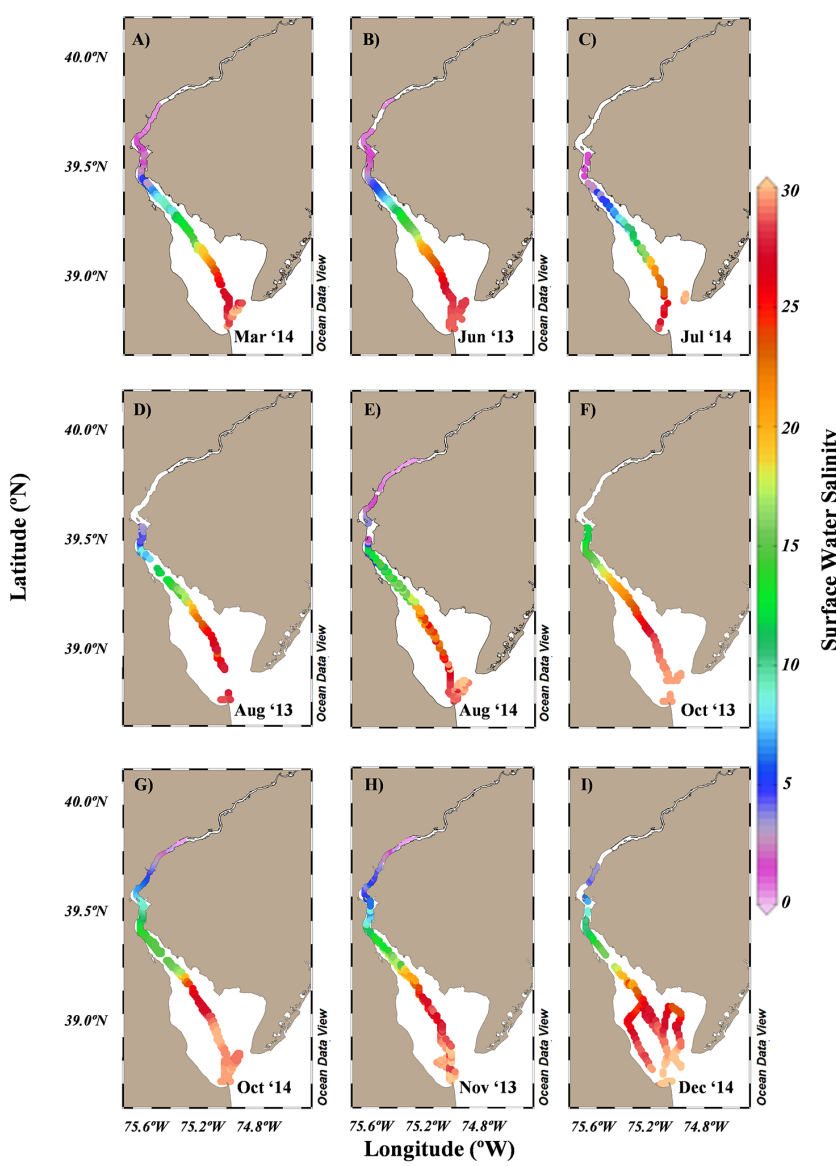

Figure 5. Spatial distributions of surface water salinity in the Delaware Estuary measured during each sampling month. The map was designed with the ODV software by R. Schlitzer (Ocean Data View software, 2015, http://odv.awi.de/).

River, with $p \mathrm{CO}_{2}$ being lowest in the cool months (March, October, and November) and highest in the warm months (June, July, and August; Table 2). During all months, the turbidity maximum zone was supersaturated in $\mathrm{CO}_{2}$ with respect to the atmosphere (atmospheric $p \mathrm{CO}_{2}: 375-398 \mu \mathrm{atm}$ ) except during March 2014 (Fig. 6a). Throughout the summer and early fall (June, July, and August), $p \mathrm{CO}_{2}$ ranged from about 650 to over $4000 \mu$ atm across the turbidity and lower urban river zones (Fig. 6b-e). In late fall (October and November), $p \mathrm{CO}_{2}$ dropped to as low as $500 \mu \mathrm{atm}$ in the turbidity maximum zone and reached $1400 \mu \mathrm{atm}$ within the lower urban river zone (Fig. 6f-h). However, the decrease in $p \mathrm{CO}_{2}$ values was not always observed as temperatures cooled. During the winter (December), surface water $p \mathrm{CO}_{2}$ values increased across the turbidity maximum zone, ranging from about 650 to $1000 \mu$ atm (Fig. 6i). As discussed later, this shift in $p \mathrm{CO}_{2}$ during winter is likely a result of opposing timing of seasonal temperature cycles and respiration versus that of river discharge rates. 
Table 2. Area average, standard deviation, and range of $p \mathrm{CO}_{2}$ and $\mathrm{CO}_{2}$ flux $\left(F_{\mathrm{CO}_{2}}\right)$ in five of the six zones in the Delaware Estuary during each cruise.

\begin{tabular}{|c|c|c|c|c|c|c|c|c|c|c|c|}
\hline & & $\begin{array}{l}\text { Mar } \\
2014\end{array}$ & $\begin{array}{l}\text { Jun } \\
2013\end{array}$ & $\begin{array}{l}\text { Jul } \\
2014 *\end{array}$ & $\begin{array}{l}\text { Aug } \\
2013^{*}\end{array}$ & $\begin{array}{l}\text { Aug } \\
2014\end{array}$ & $\begin{array}{l}\text { Oct } \\
2013^{*}\end{array}$ & $\begin{array}{l}\text { Oct } \\
2014\end{array}$ & $\begin{array}{l}\text { Nov } \\
2013\end{array}$ & $\begin{array}{l}\text { Dec } \\
2014^{*}\end{array}$ & $\begin{array}{l}\text { Annual } \\
\text { average }\end{array}$ \\
\hline \multicolumn{12}{|c|}{$\begin{array}{l}\text { Average } p \mathrm{CO}_{2} \\
(\mu \mathrm{atm})\end{array}$} \\
\hline \multirow[t]{2}{*}{ Lower bay } & Mean \pm SD & $230 \pm 23$ & $477 \pm 11$ & $473 \pm 52$ & $384 \pm 42$ & $315 \pm 59$ & $421 \pm 6$ & $405 \pm 8$ & $387 \pm 3$ & $596 \pm 11$ & 410 \\
\hline & Range & 194-267 & $456-528$ & $397-648$ & $317-491$ & $243-432$ & $413-437$ & $395-419$ & $380-393$ & $570-627$ & \\
\hline \multirow[t]{2}{*}{ Mid-bay } & Mean \pm SD & $198 \pm 8$ & $540 \pm 66$ & $559 \pm 97$ & $530 \pm 36$ & $250 \pm 16$ & $465 \pm 22$ & $422 \pm 2$ & $390 \pm 8$ & $590 \pm 21$ & 438 \\
\hline & Range & $187-232$ & $464-759$ & $402-777$ & $464-607$ & $223-310$ & $429-516$ & $417-431$ & $378-415$ & $566-654$ & \\
\hline \multirow[t]{2}{*}{ Upper bay } & Mean \pm SD & $289 \pm 47$ & $919 \pm 192$ & $917 \pm 97$ & $680 \pm 58$ & $470 \pm 98$ & $566 \pm 39$ & $463 \pm 19$ & $434 \pm 11$ & $658 \pm 26$ & 599 \\
\hline & Range & $225-401$ & $645-1374$ & $768-1149$ & $594-846$ & $312-697$ & $508-651$ & $428-483$ & $411-461$ & $597-744$ & \\
\hline \multirow{2}{*}{$\begin{array}{l}\text { Turbidity } \\
\text { maximum } \\
\text { zone }\end{array}$} & Mean \pm SD & $595 \pm 121$ & $2087 \pm 499$ & $1473 \pm 162$ & $1237 \pm 139$ & $1102 \pm 317$ & $726 \pm 34$ & $575 \pm 79$ & $542 \pm 61$ & $786 \pm 39$ & 1014 \\
\hline & Range & $397-854$ & $1327-2981$ & $1141-1680$ & $837-1370$ & $689-1866$ & $645-754$ & $481-737$ & $457-709$ & $711-1000$ & \\
\hline \multirow[t]{2}{*}{ Urban river } & Mean \pm SD & $868 \pm 48$ & $3287 \pm 163$ & $2994 \pm N / A$ & $2542 \pm \mathrm{N} / \mathrm{A}$ & $2310 \pm 589$ & $1199 \pm N / A$ & $816 \pm 133$ & $880 \pm 179$ & $878 \pm$ N/A & 1753 \\
\hline & Range & $762-945$ & $3007-3600$ & N/A & N/A & $1822-4000$ & N/A & $640-1330$ & $615-1450$ & N/A & \\
\hline \multicolumn{12}{|c|}{$\begin{array}{l}\text { Average } F_{\mathrm{CO}_{2}} \\
\left(\mathrm{mmol} \mathrm{m}{ }^{-2} \mathrm{~d}^{-1}\right)\end{array}$} \\
\hline \multirow[t]{2}{*}{ Lower bay } & Mean \pm SD & $-15.4 \pm 2.3$ & $3.8 \pm 0.5$ & $4.4 \pm 2.5$ & $3.8 \pm 1.9$ & $-3.0 \pm 2.7$ & $1.6 \pm 0.4$ & $0.8 \pm 0.6$ & $-1.2 \pm 0.3$ & $13.5 \pm 1.0$ & 0.9 \\
\hline & Range & $-19.4-(-12.0)$ & $2.8-6.2$ & $0.5-13.1$ & $0.8-8.5$ & $-6.4-2.5$ & $1.1-2.6$ & $0.1-1.8$ & $-1.9-(-0.7)$ & $11.6-15.7$ & \\
\hline \multirow[t]{2}{*}{ Mid-bay } & Mean \pm SD & $-20.0 \pm 0.6$ & $6.8 \pm 3.2$ & $11.1 \pm 6.8$ & $10.2 \pm 1.6$ & $-6.7 \pm 0.7$ & $4.8 \pm 1.8$ & $2.0 \pm 0.1$ & $-1.1 \pm 0.7$ & $13.5 \pm 2.0$ & 2.3 \\
\hline & Range & $-21.0-(-17.8)$ & $3.2-17.4$ & $0.8-27.8$ & $7.3-13.6$ & $-8.0-(-3.9)$ & $2.1-9.0$ & $1.6-2.7$ & $-2.1-1.3$ & $11.2-19.3$ & \\
\hline \multirow[t]{2}{*}{ Upper bay } & Mean \pm SD & $-12.1 \pm 4.9$ & $25.3 \pm 9.5$ & $39.5 \pm 7.3$ & $16.8 \pm 2.6$ & $5.7 \pm 6.0$ & $13.0 \pm 2.9$ & $5.0 \pm 1.4$ & $3.4 \pm 1.2$ & $19.7 \pm 2.0$ & 12.9 \\
\hline & Range & $-18.4-(-0.5)$ & $11.8-48.0$ & $26.9-54.7$ & $13.0-24.3$ & $-3.8-19.0$ & $8.4-18.6$ & $2.5-6.5$ & $0.9-5.9$ & $14.2-25.1$ & \\
\hline \multirow{2}{*}{$\begin{array}{l}\text { Turbidity } \\
\text { maximum } \\
\text { zone }\end{array}$} & Mean \pm SD & $15.9 \pm 9.6$ & $83.9 \pm 25.2$ & $63.5 \pm 2.9$ & $42.2 \pm 6.9$ & $37.1 \pm 13.9$ & $21.1 \pm 0.9$ & $12.3 \pm 5.1$ & $10.1 \pm 3.0$ & $26.7 \pm 1.9$ & 34.8 \\
\hline & Range & $-0.9-36.9$ & $45.6-129.1$ & $54.3-65.5$ & $23.9-47.6$ & $18.6-71.9$ & $18.3-21.7$ & $6.3-23.6$ & $5.6-19.7$ & $23.3-44.8$ & \\
\hline \multirow[t]{2}{*}{ Urban river } & Mean \pm SD & $38.3 \pm 4.3$ & $144.8 \pm 8.1$ & $131.0 \pm$ N/A & $109.8 \pm \mathrm{N} / \mathrm{A}$ & $98.9 \pm 25.9$ & $52.1 \pm$ N/A & $30.2 \pm 8.6$ & $31.0 \pm 8.1$ & $32.1 \pm \mathrm{N} / \mathrm{A}$ & 74.2 \\
\hline & Range & $33.6-45.5$ & $130.4-160.0$ & N/A & N/A & $83.0-175.4$ & N/A & $17.8-64.1$ & $20.9-66.4$ & N/A & \\
\hline
\end{tabular}

Surface water $p \mathrm{CO}_{2}$ exhibited strong seasonal variations in the Delaware Bay as well (Fig. 6a-i). In March 2014, most likely due to a strong biological bloom and low temperature (Fig. 4a), the entire bay system (upper, middle, and lower) was undersaturated in $\mathrm{CO}_{2}$ with respect to the atmosphere (Table 2). In particular, $p \mathrm{CO}_{2}$ reached as low as $160 \mu$ atm in the mid-bay (Fig. 6a). During the warmer summer months (June, July, and August), $p \mathrm{CO}_{2}$ in the bay remained around 400 to $500 \mu \mathrm{atm}$, with occasional undersaturation occurring in the mid-bay region (Fig. 6b-e). In August 2014, low $p \mathrm{CO}_{2}$ ranging from about 200 to $350 \mu$ atm was observed throughout much of the mid- and lower bay regions (Fig. 6e). In contrast, during the late fall, $p \mathrm{CO}_{2}$ values were fairly homogenous throughout the mid- and lower bay (400-450 $\mu$ atm in October 2013 and 2014 and 375-415 $\mu$ atm in November 2013) and slightly higher $p \mathrm{CO}_{2}$ occurring in the upper bay (Fig. 6f-h). In December 2014, $p \mathrm{CO}_{2}$ increased throughout all regions of the bay, with $p \mathrm{CO}_{2}$ values ranging from 500 to $650 \mu$ atm (Fig. 6i). While it remains unclear what supports these elevated pCO2 values, stratification of subsurface waters in late fall followed by strong winter mixing during winter (December 2014) and a 2-fold increase in river discharge could explain the elevated $p \mathrm{CO}_{2}$ values observed throughout the mid- and the lower bay systems (Fig. 4b).

\subsection{Air-water $\mathrm{CO}_{2}$ fluxes}

The urban river and turbidity maximum zone served as strong sources of $\mathrm{CO}_{2}$ to the atmosphere and were positive during all months (Table 2). Across the upper to lower bay portions of the estuary, uptake of $\mathrm{CO}_{2}$ from the atmosphere was greatest during spring (March), ranging from $F_{\mathrm{CO}_{2}}=-12.1$ to $-20.0 \mathrm{mmol} \mathrm{m}^{-2} \mathrm{~d}^{-1}$ (Table 2). The $\mathrm{CO}_{2}$ uptake flux was highest in March 2014 in the mid-bay ( $-20.0 \mathrm{mmol} \mathrm{m}^{-2} \mathrm{~d}^{-1}$ ), while the highest $\mathrm{CO}_{2}$ degassing flux occurred in June 2014 in the urban river $\left(144.8 \mathrm{mmol} \mathrm{m}^{-2} \mathrm{~d}^{-1}\right.$; Table 2). Air-water $\mathrm{CO}_{2}$ fluxes in the upper to lower bay regions decreased in early winter (December) to a minimum in early spring (March), followed by an increase to an annual maximum in early summer (June). In the turbidity maximum zone and urban river, area-averaged $\mathrm{CO}_{2}$ fluxes followed the same seasonal decrease in spring and increase in summer but reached an annual minimum in late fall instead of early spring. In winter (December), the mid- and lower bays, which were typically sinks or weak sources of $\mathrm{CO}_{2}$, exhibited relatively strong $\mathrm{CO}_{2}$ fluxes to the atmosphere.

\section{4 $\mathrm{CO}_{2}$ distribution across the salinity gradient}

To further investigate $p \mathrm{CO}_{2}$ variations along the Delaware Estuary, we examined distributions of $p \mathrm{CO}_{2}$ across the salinity gradient. Due to limited area and salinity coverage, surveys conducted in August and October 2013 were excluded for this assessment. In all months, $p \mathrm{CO}_{2}$ versus salinity followed a concave upward trend towards the river end-member (Fig. 7). The seasonal variation between $p \mathrm{CO}_{2}$ values was largest at low salinities around 0 to 5, with $p \mathrm{CO}_{2}$ values in the summer (June, July, and August) nearly 2-fold greater than those observed in the spring (March) and fall (October and November) seasons (Fig. 7). In all seasons, $p \mathrm{CO}_{2}$ was supersaturated with respect to the atmosphere from salinities 


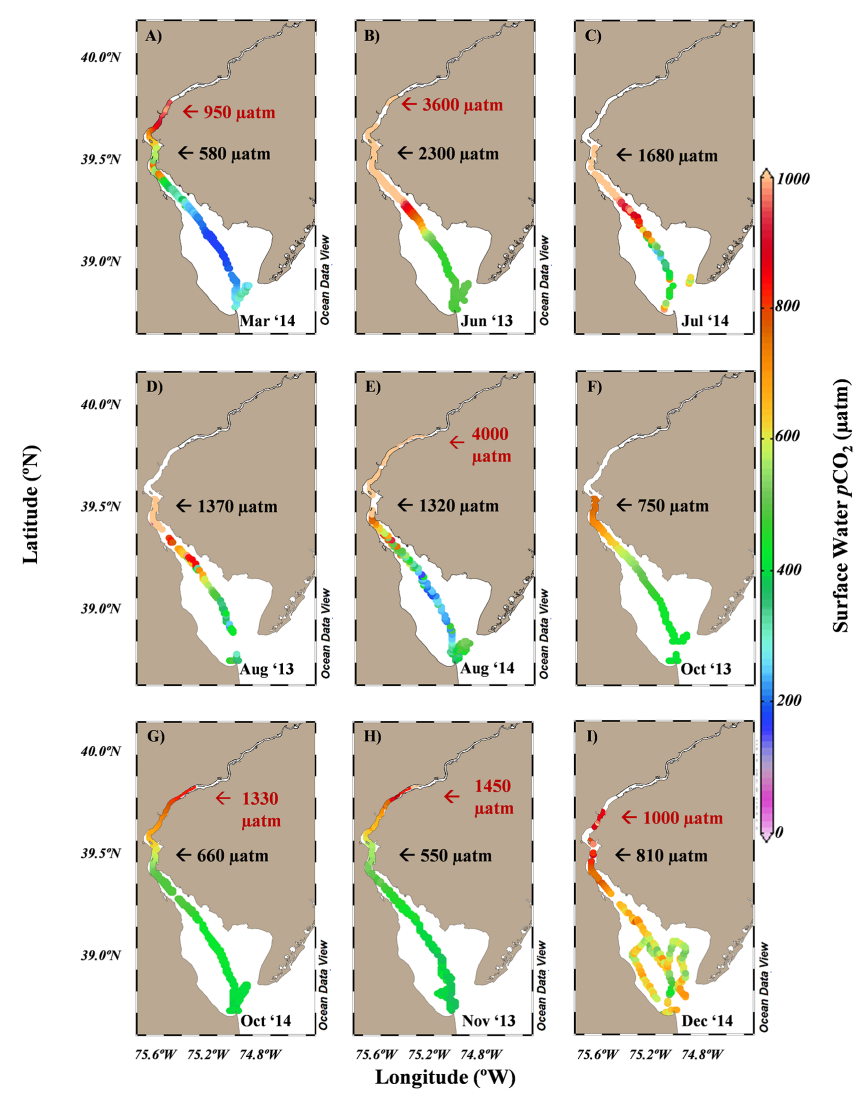

Figure 6. Spatial distributions of surface water $p \mathrm{CO}_{2}$ in the Delaware Estuary measured during each sampling month. Black and red arrows show surface water $p \mathrm{CO}_{2}$ values at the Chesapeake and Delaware Canal and the northern end-member of each survey, respectively. The map was designed with the ODV software by R. Schlitzer (Ocean Data View software, 2015, http://odv.awi.de/).

0 to 5. In spring, undersaturated $p \mathrm{CO}_{2}$ was observed over the widest salinity range from 7.5 to 30 . In summer, undersaturated $p \mathrm{CO}_{2}$ was generally not observed except at moderate salinities around 17 to 28 in August. In fall, $p \mathrm{CO}_{2}$ values were near atmospheric concentrations around mid-salinity waters and were only undersaturated at salinities greater than 25. In winter (December), $p \mathrm{CO}_{2}$ values were always supersaturated with respect to the atmosphere across the entire salinity range. Seasonally, the Delaware Estuary served as a strong $\mathrm{CO}_{2}$ sink $\left(-5.0 \pm 6.0\right.$ mol- $\left.\mathrm{C} \mathrm{m}^{-2} \mathrm{yr}^{-1}\right)$ in the spring, a strong source $\left(4.9 \pm 8.1 \mathrm{~mol}-\mathrm{C} \mathrm{m}^{-2} \mathrm{yr}^{-1}\right)$ in the summer, a weak source $\left(1.0 \pm 2.4 \mathrm{~mol}-\mathrm{C} \mathrm{m}^{-2} \mathrm{yr}^{-1}\right)$ in the fall, and a strong source $\left(5.7 \pm 1.9 \mathrm{~mol}-\mathrm{C} \mathrm{m}^{-2} \mathrm{yr}^{-1}\right)$ in the winter. While low-salinity waters were strong $\mathrm{CO}_{2}$ sources, proportionally these upper regions $(0 \leq S<10)$ were small in comparison to the total estuarine study area. In turn, their areaaveraged contribution $\left(27.1 \pm 6.4\right.$ mol- $\left.\mathrm{C} \mathrm{m}^{-2} \mathrm{yr}^{-1}\right)$ to overall regional flux $\left(2.4 \pm 4.8\right.$ mol- $\left.\mathrm{C} \mathrm{m}^{-2} \mathrm{yr}^{-1}\right)$ is minor. Thus, the Delaware Estuary as a whole acts as a relatively weak $\mathrm{CO}_{2}$ source $\left(2.4 \pm 4.8\right.$ mol- $\left.\mathrm{C} \mathrm{m}^{-2} \mathrm{yr}^{-1}\right)$, which is in great

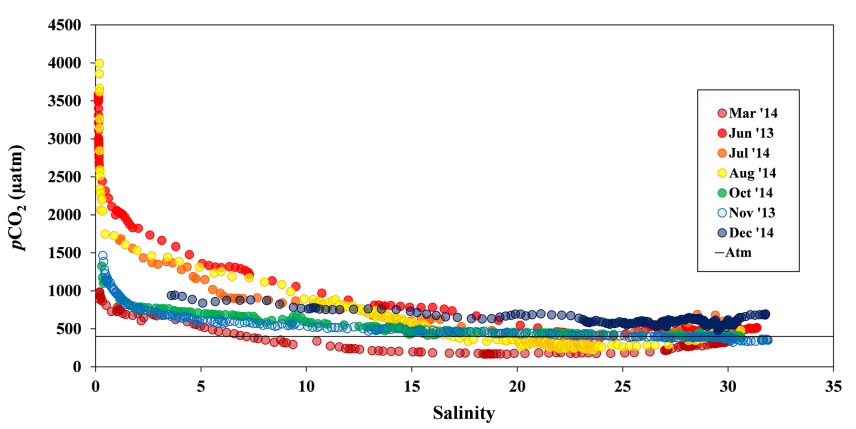

Figure 7. Measured surface water $p \mathrm{CO}_{2}$ against the salinity gradient during each sampling month in the Delaware Estuary.

contrast to many river estuaries that are strong $\mathrm{CO}_{2}$ sources (26 \pm 21 mol- $-\mathrm{C} \mathrm{m}^{-2} \mathrm{yr}^{-1}$; Borges and Abril, 2011).

\subsection{Seasonal variations in temperature-normalized $\mathrm{pCO}_{2}$}

Seasonal distributions of $p \mathrm{CO}_{2 \mathrm{obs}}$ at $13.3^{\circ} \mathrm{C}$, which indicate impacts of non-thermal processes (biological and mixing), varied noticeably throughout the year and across salinity intervals (Fig. 8). Typically, $p \mathrm{CO}_{2 \text { obs }}$ at $13.3{ }^{\circ} \mathrm{C}$ was greatest during the early and mid-winter season (December and January) except in the $0-5$ salinity interval (mostly turbidity maximum zone and urban river) when $p \mathrm{CO}_{2 \text { obs }}$ at $13.3{ }^{\circ} \mathrm{C}$ reached its maximum in June. Coupled with decreasing flow, in the $0-5$ salinity interval, $p \mathrm{CO}_{2 \text { obs }}$ at $13.3^{\circ} \mathrm{C}$ decreased from June to an annual minimum in October. In the midsalinity waters $(5 \leq S \leq 20), p \mathrm{CO}_{2 \mathrm{obs}}$ at $13.3{ }^{\circ} \mathrm{C}$ decreased from mid-winter to an annual minimum in March, followed by an increase to a secondary maximum in June. In contrast, in the high-salinity waters $(20 \leq S \leq 30)$ of the lower bay, where biological removal of $\mathrm{CO}_{2}$ was generally strong, annual minimums were observed in August. The annual distribution of $p \mathrm{CO}_{2 \text { mean }}$ at $T_{\mathrm{obs}}$, which indicates the impact of the seasonal thermal cycle, followed typical bell-shaped curves across all salinity intervals, with the lowest values occurring in winter and an annual maximum occurring in July.

\section{Discussion}

The seasonal and spatial distributions of estuarine $p \mathrm{CO}_{2}$ are governed by the dynamic interaction between water temperature; horizontal and vertical mixing processes; biological processes; and $\mathrm{CO}_{2}$ contributions from the river, ocean, and estuarine zone (Jiang et al., 2008a; Borges and Abril, 2011; Hunt et al., 2014). In the estuarine zone, the addition or removal of $\mathrm{CO}_{2}$ includes net ecosystem metabolism, DIC exchange with intertidal marshes, sediments, groundwater inputs, air-water gas exchanges, and other estuarine contributing processes (Jiang et al., 2008a). In the following sections, we evaluate the impact that seasonal temperature changes 
and river discharge rates have on surface water $p \mathrm{CO}_{2}$ distributions' river and estuarine $\mathrm{CO}_{2}$ inputs, and river-borne $\mathrm{CO}_{2}$ fluxes throughout the Delaware Estuary.

\subsection{Temperature vs. biological effects on $\mathrm{pCO}_{2}$}

Similar to other estuaries (Borges and Abril, 2011), seasonal temperature changes provided a first control on the observed seasonal changes in $p \mathrm{CO}_{2 \text { obs }}$ (low in the winter and high in the summer, Figs. 4a and 7). This is further reflected in the fact that temperature-normalized $p \mathrm{CO}_{2}$ was always higher than in situ $p \mathrm{CO}_{2}$ in the winter but lower than in situ $p \mathrm{CO}_{2}$ in the summer (Fig. 8). Presumably, then, seasonal patterns of the temperature-normalized $p \mathrm{CO}_{2}$ reflect how non-thermal processes (mixing and biological) influence in situ $p \mathrm{CO}_{2}$. For example, in the urban river and turbidity maximum zones $(S<5)$, high $p \mathrm{CO}_{2 \text { obs }}$ at $13.3{ }^{\circ} \mathrm{C}$ in the spring and winter may reflect both river inputs and strong respiratory $\mathrm{CO}_{2}$ production. Low $p \mathrm{CO}_{2 \text { obs }}$ at $13.3^{\circ} \mathrm{C}$ during the warmer months likely reflects the removal of $\mathrm{CO}_{2}$ due to various non-thermal processes. During the warmer months from May to October, Yoshiyama and Sharp (2006) found elevated nitrite $\left(\mathrm{NO}_{2}\right)$ concentrations in the urban river when nitrification and primary production were highest. In addition, high $\mathrm{NO}_{2}$ concentrations were observed in the mid-bay in summer, when primary production was maximal (Pennock and Sharp, 1994). Comparably, $p \mathrm{CO}_{2 \text { mean }}$ at $T_{\text {obs }}$ (changes due to the seasonal thermal cycle) trends were opposite to the trend of $p \mathrm{CO}_{2 \mathrm{obs}}$ at $13.3^{\circ} \mathrm{C}$ with lower than $p \mathrm{CO}_{2 \text { obs }}$ values in the winter and higher than $p \mathrm{CO}_{2 \mathrm{obs}}$ values in the summer. These opposing signals suggest that increases in surface water $p \mathrm{CO}_{2}$ due to winter-to-summer warming are partially compensated for by the reduction of surface water $p \mathrm{CO}_{2}$ due to mixing processes and/or biological removal of $\mathrm{CO}_{2}$ (Takahashi et al., 2002). Sharp et al. (2009) found that, during the March-April period, ammonium $\left(\mathrm{NH}_{4}\right)$, phosphate $\left(\mathrm{PO}_{4}\right)$, and silicate $(\mathrm{Si})$ concentrations were heavily depleted in the mid- and lower bay regions due to extensive spring blooms. Similarly, but in the opposite direction, the reduction in surface water $p \mathrm{CO}_{2}$ due to fall-to-winter cooling is partially compensated for by the elevation of surface water $p \mathrm{CO}_{2}$ caused by various nonthermal processes (Fig. 8).

We further examine the relative importance of the temperature and biological effects in each salinity interval by calculating the ratio of $\Delta p \mathrm{CO}_{2 \text { temp }}$ to $\Delta p \mathrm{CO}_{2 \mathrm{bio}}(T / B)$. Using similar methods as performed in Takahashi et al. (2002), we calculate the thermal effects on surface water $p \mathrm{CO}_{2}$ in each salinity interval as follows:

$\Delta p \mathrm{CO}_{2 \text { thermal }}=\left(p \mathrm{CO}_{2 \text { mean }} \text { at } T_{\mathrm{obs}}\right)_{\max }-\left(p \mathrm{CO}_{2 \text { mean }} \text { at } T_{\mathrm{obs}}\right)_{\min }$,

where $\left(p \mathrm{CO}_{2 \text { mean }} \text { at } \mathrm{T}_{\text {obs }}\right)_{\text {max }}$ and $\left(p \mathrm{CO}_{2 \text { mean }} \text { at } \mathrm{T}_{\text {obs }}\right)_{\text {min }}$ are the maximum and minimum $p \mathrm{CO}_{2 \text { mean }}$ at $\mathrm{T}_{\mathrm{obs}}$ values, respectively. In other words, the thermal effects on the mean annual $p \mathrm{CO}_{2}$ value are represented by the seasonal amplitude of ( $p \mathrm{CO}_{2 \text { mean }}$ at $\left.T_{\mathrm{obs}}\right)$ values computed using Eq. (7).
Likewise, the non-thermal effects (biological and mixing processes) on surface water $p \mathrm{CO}_{2}$ were calculated as follows (Takahashi et al., 2002):

$$
\begin{aligned}
& \Delta p \mathrm{CO}_{2 \text { non-thermal }}=\left(p \mathrm{CO}_{2 \text { obs }} \text { at } 13.3^{\circ} \mathrm{C}\right)_{\max } \\
& -\left(p \mathrm{CO}_{2 \text { obs }} \text { at } 13.3^{\circ} \mathrm{C}\right)_{\min },
\end{aligned}
$$

where $\left(p \mathrm{CO}_{2 \text { obs }} \text { at } 13.3^{\circ} \mathrm{C}\right)_{\max }$ and $\left(p \mathrm{CO}_{2 \text { obs }} \text { at } 13.3^{\circ} \mathrm{C}\right)_{\min }$ are the maximum and minimum $p \mathrm{CO}_{2 \mathrm{obs}}$ at $13.3^{\circ} \mathrm{C}$ values, respectively. Thus, the non-thermal effects on surface water $p \mathrm{CO}_{2}\left(p \mathrm{CO}_{2 \text { obs }}\right.$ at $\left.13.3^{\circ} \mathrm{C}\right)$ are represented by the seasonal amplitude of $p \mathrm{CO}_{2}$ values corrected to the 10-year (2004-2014) annual mean temperature using Eq. (6). The relative importance of these effects in each salinity interval can be expressed as the difference between $\Delta p \mathrm{CO}_{2 \text { thermal }}$ and $\Delta p \mathrm{CO}_{2 \text { non-thermal }}(T-B)$ or the ratio of $\Delta p \mathrm{CO}_{2 \text { thermal }}$ to $\triangle p \mathrm{CO}_{2 \text { non-thermal }}(T / B)$. In estuarine regions where thermal effects on surface water $p \mathrm{CO}_{2}$ exceed non-thermal effects, the $(T / B)$ ratio is greater than 1 or $(T-B)$ is positive, whereas in areas where non-thermal effects dominate, the $(T / B)$ ratio is less than 1 or $(T-B)$ is negative. Based on our results, temperature was a dominant factor in controlling surface water $p \mathrm{CO}_{2}$ in low-salinity waters $(0 \leq S \leq 10$; mainly the urban river and turbidity maximum zone), with $T / B$ ratios ranging from 1.30 to 1.68 (Table 4). As salinity increased, both $\Delta p \mathrm{CO}_{2 \text { thermal }}$ and $\Delta p \mathrm{CO}_{2 \text { non-thermal de- }}$ creased (Table 4). The decrease in $\Delta p \mathrm{CO}_{2 \text { thermal }}$ may be attributed to the reduction in river water temperatures at the ocean end-member (Hunt et al., 2014). In comparison to the upper tidal river, low $T / B$ ratios ranging from 0.69 to 0.80 were observed in mid-salinity waters $(15 \leq S \leq 25$; mainly the mid- and lower bay), suggesting that $p \mathrm{CO}_{2}$ distributions in the Delaware Bay are largely governed by biological and/or mixing processes.

\subsection{Influence of river-borne $\mathrm{CO}_{2}$ on estuarine degassing}

The potential emission of river-borne $\mathrm{CO}_{2}$ was estimated based on the concept of excess $\mathrm{CO}_{2}$, the difference between the in situ DIC at zero salinity and a theoretical DIC value at atmospheric equilibrium ( $\triangle \mathrm{DIC}$; Abril et al., 2000; Borges et al., 2006). The theoretical DIC was computed using in situ TA values and an atmospheric $p \mathrm{CO}_{2}$ of $395 \mu \mathrm{atm}$. Riverborne $\mathrm{CO}_{2}$ fluxes were calculated as the product of $\triangle \mathrm{DIC}$ and the combined river discharges from the Schuylkill and Delaware rivers for each month divided by the estuarine surface area. Generally, as freshwater residence time increases (river discharge decreases), river-borne $\mathrm{CO}_{2}$ fluxes decrease (Borges et al., 2006). As more river-borne $\mathrm{CO}_{2}$ is released into the atmosphere in the upper estuary due to increased residence time, leaving less river-borne $\mathrm{CO}_{2}$ for degassing in the lower estuary, the overall contributions of $\mathrm{CO}_{2}$ emissions are largely shaped by the net community production in the mixed layer (ML NCP) in the mid- to high-salinity estuarine 

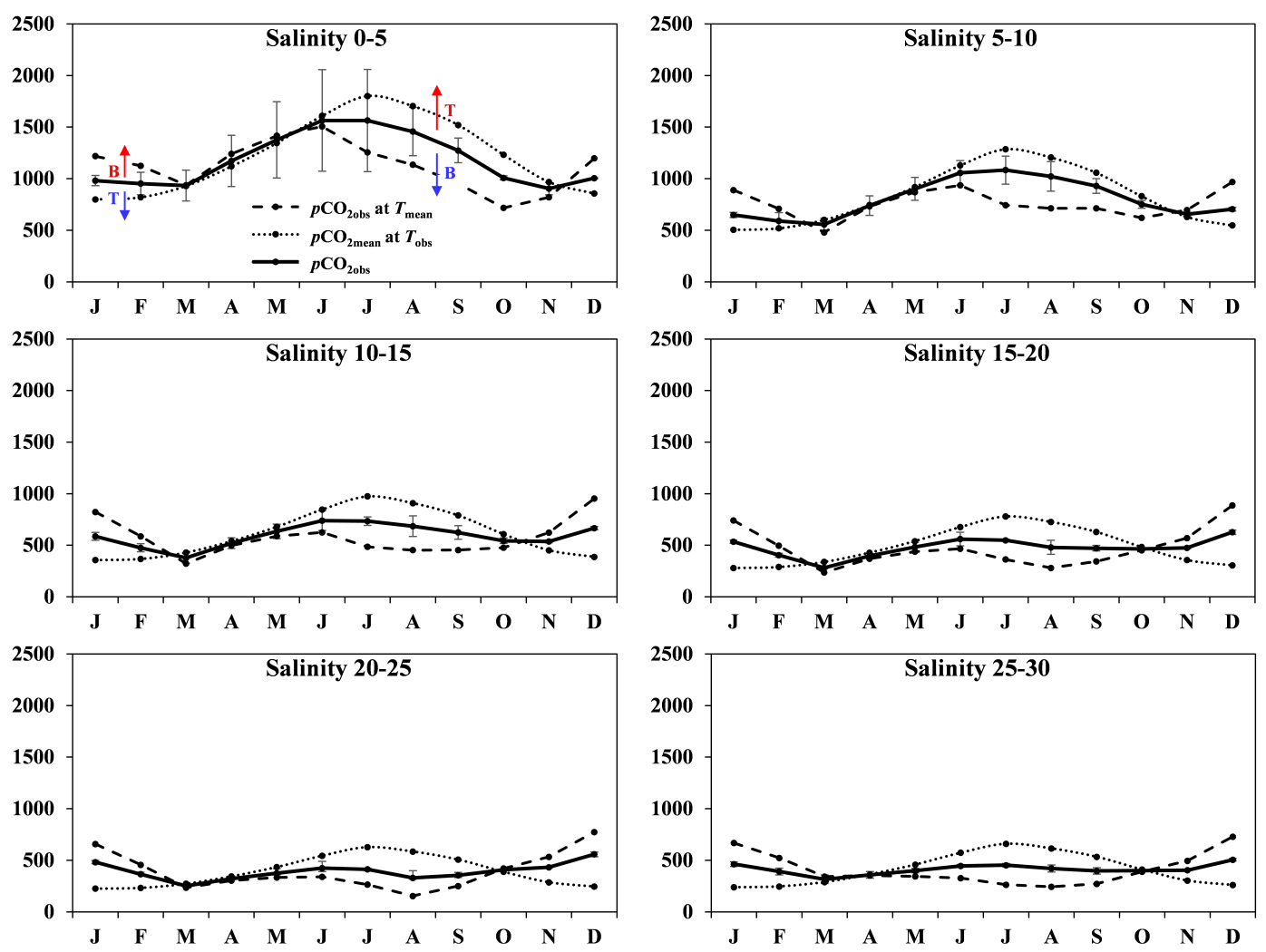

Figure 8. Salinity-binned intervals of temperature-normalized observed $p \mathrm{CO}_{2}$ values at $13.3{ }^{\circ} \mathrm{C}$, annual mean, area-averaged $p \mathrm{CO}_{2}$ values at in situ temperature, and observed $p \mathrm{CO}_{2}$ values in the Delaware Estuary over the year. Red arrows indicate increases in $p \mathrm{CO}_{2}$ and blue arrows indicate decreases in $p \mathrm{CO}_{2}$. The symbol T represents changes in $p \mathrm{CO}_{2}$ due to thermal processes and the symbol $\mathrm{B}$ represents fluctuations in $p \mathrm{CO}_{2}$ due to non-thermal processes. Error bars represent 1 standard deviation of the mean value for each month.

zones (Abril et al., 2000; Borges et al., 2006). In comparison, as freshwater residence time decreases (river discharge increases), DIC enrichment from ML NCP is reduced and river-borne $\mathrm{CO}_{2}$ fluxes increase. In certain cases, such as the Rhine Estuary or other systems with extremely rapid flushing times, residence time is so short that not all of the riverborne $\mathrm{CO}_{2}$ is ventilated to the atmosphere in the estuarine zone (Borges and Frankignoulle, 2002; Borges et al., 2006). In turn, the potential emission of river-borne $\mathrm{CO}_{2}$ is higher than the actual observed air-water $\mathrm{CO}_{2}$ fluxes from the estuary (Borges et al., 2006).

Positive correlations between river-borne and air-water $\mathrm{CO}_{2}$ fluxes illustrate the importance of river inputs to $\mathrm{CO}_{2}$ degassing fluxes (Fig. 9). In the Delaware Estuary, the largest river-borne $\mathrm{CO}_{2}$ flux was observed during the highest flow month of June 2013, with river $\mathrm{CO}_{2}$ flux accounting for 119 and $60 \%$ of the overall $\mathrm{CO}_{2}$ degassing flux in the urban river and turbidity maximum zone, respectively (Fig. 9). Moreover, during the high-flow month of March 2014, riverborne $\mathrm{CO}_{2}$ fluxes exceeded 200 and $150 \%$ of the overall $\mathrm{CO}_{2}$ degassing fluxes in the urban river and turbidity maximum zone, respectively (Fig. 9). Presumably, the higher riverborne $\mathrm{CO} 2$ fluxes than overall $\mathrm{CO}_{2}$ fluxes in March are due to the combined influence of increased river discharge coupled with large $\mathrm{CO}_{2}$ consumption in the estuary (Figs. $4 \mathrm{~b}$ and $5 \mathrm{a}$ ). This is consistent with the observed low $p \mathrm{CO}_{2}$ and high $\mathrm{O}_{2}$ values (Fig. 6a; Cai, unpublished data). In contrast, in July and August 2014, air-water $\mathrm{CO}_{2}$ fluxes exceeded riverborne $\mathrm{CO}_{2}$ fluxes, indicating strong estuarine $\mathrm{CO}_{2}$ production. Such internal estuarine $\mathrm{CO}_{2}$ production is most likely due to respiration in the water column, but may also include other inputs such as benthic respiration and net respiration from surrounding intertidal marshes. In turn, while correlations between river-borne and air-water $\mathrm{CO}_{2}$ fluxes were exhibited, differences between the two fluxes suggest that the input of $\mathrm{CO}_{2}$ from other estuarine sources is important.

\subsection{Internal estuarine production versus river $\mathrm{CO}_{2}$ input}

Our results illustrate that both the river and the estuarine zone contribute to $\mathrm{CO}_{2}$ inputs in the Delaware Estuary (Fig. 10). Combined river $\mathrm{CO}_{2}$ input and internal estuarine production was highest in the urban river $\left(87.8\right.$ to $\left.255.4 \mu \mathrm{mol} \mathrm{L}^{-1}\right)$ and lowest in the lower bay ( -38.8 to $7.0 \mu \mathrm{mol} \mathrm{L}^{-1}$; Fig. 10). In the tidal river, internal estuarine production exhibited clear 

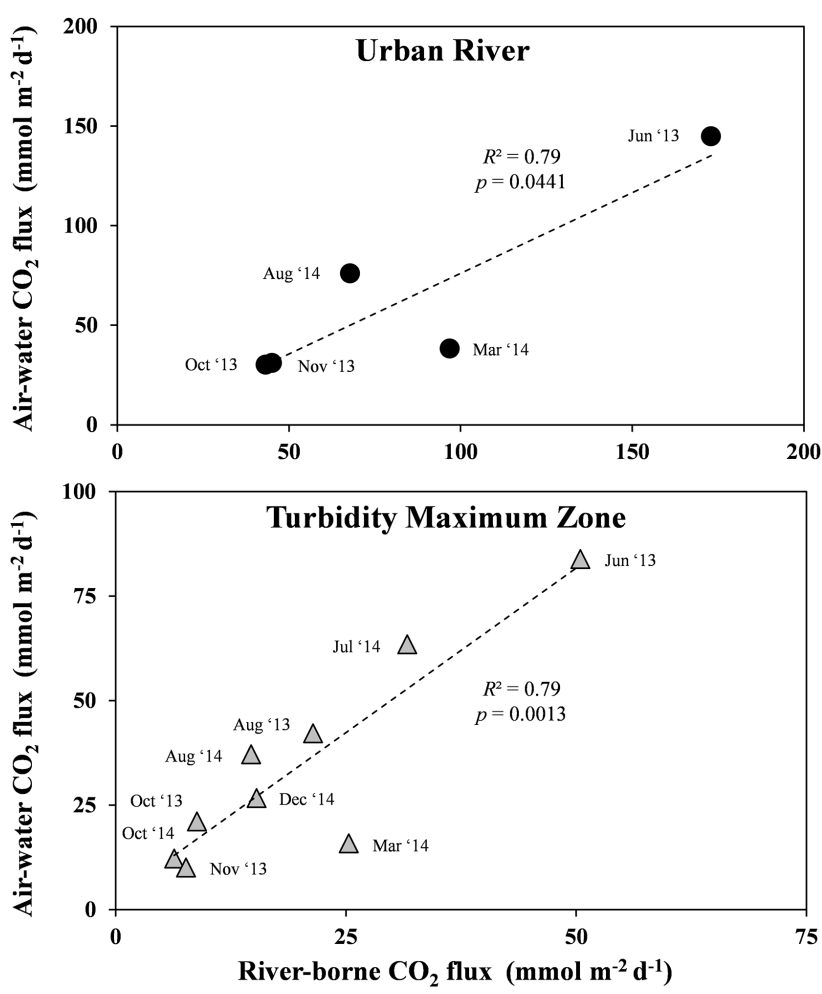

Figure 9. Air-water $\mathrm{CO}_{2}$ fluxes against river-borne $\mathrm{CO}_{2}$ fluxes in the urban river and turbidity maximum zone of the Delaware Estuary. Note the different axes used for the urban river and turbidity maximum zone.

seasonal trends, with $\mathrm{CO}_{2}$ contributions being lowest in the spring (March), highest in the summer (June and August), and medium in the fall (October and November). Strong seasonal trends in internal estuarine production were also observed in the bay regions. During spring and late summer (March and August 2014), internal estuarine $\mathrm{CO}_{2}$ signals were negative in the mid- and lower bay zones and reached as much as 8 -fold greater than total river $\mathrm{CO}_{2}$ inputs, ranging from -22.9 to $-100.4 \mu \mathrm{mol} \mathrm{L}^{-1}$ (Fig. 10). Thus, the majority of river $\mathrm{CO}_{2}$ input was heavily compensated for by the biological removal of $\mathrm{CO}_{2}$ in the bay waters. In addition, during the spring season (March), high $\mathrm{CO}_{2}$ consumption was also observed in the upper bay, with internal estuarine $\mathrm{CO}_{2}$ signals $\left(-30.7 \mu \mathrm{mol} \mathrm{L}^{-} 1\right)$ exceeding total river $\mathrm{CO}_{2}$ contribution $\left(25.7 \mu \mathrm{mol} \mathrm{L}^{-1}\right.$; Fig. 10). Depending on river discharge rates, the freshwater residence time in the Delaware Estuary ranges from about 40 to 90 days (Ketchum, 1952). Due to smaller physical sizes, freshwater residence time in the upper tidal river is much shorter (Table 3). Thus, the percentage of river-borne $\mathrm{CO}_{2}$ in the upper Delaware Estuary is large (Fig. 10), and that percentage decreases in the midand lower bays, which have longer residence times and high biological $\mathrm{CO}_{2}$ removal (Sharp, 1983).
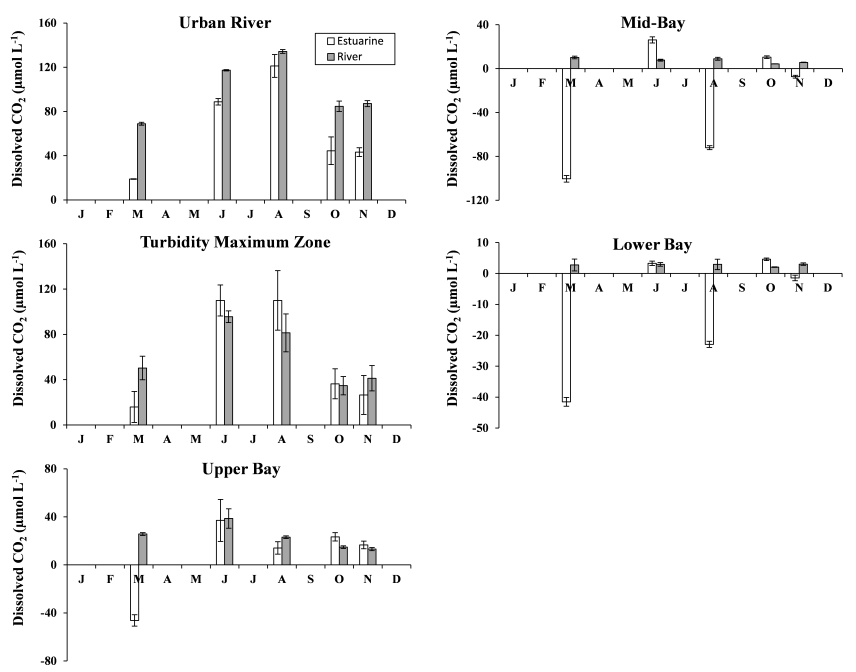

Figure 10. Dissolved $\mathrm{CO}_{2}$ concentrations (normalized to $13.3{ }^{\circ} \mathrm{C}$, area-averaged) due to river inputs and internal estuarine sources in each region of the Delaware Estuary. Note the different axes used across all regions of the estuary. Error bars represent 1 standard deviation of the mean value for each month.

\subsection{Assumptions and limitations}

While this study serves as the first air-water $\mathrm{CO}_{2}$ flux product in the Delaware Estuary, there are several limitations. First, the lack of cross-bay transects (east to west), except in December 2014, limits our knowledge of surface water $p \mathrm{CO}_{2}$ distributions in shallow water regions of the bay system. Due to various biological and physical processes (i.e., influence from nearby tidal marshes, tributaries, or estuarine circulation forces), surface water $p \mathrm{CO}_{2}$ may vary from within the main channel to the perimeters of the estuary. Jiang et al. (2008a) found that surface water $p \mathrm{CO}_{2}$ and airwater $\mathrm{CO}_{2}$ flux in the marine-dominated Sapelo and Doboy sounds paralleled seasonal temperature changes and net $\mathrm{CO}_{2}$ inputs from within the estuarine zone. Due to intense productivity of vegetation in the surrounding salt marshes, extensive accumulation of organic carbon occurs during spring and early summer (Dai and Wiegert, 1996; Jiang et al., 2008a). During late summer and early fall, increased surface water temperatures coupled with tidal flushing of intertidal marsh waters and the decomposition of dead plants contribute to high $\mathrm{CO}_{2}$ degassing in these estuaries (Dai and Wiegert, 1996; Cai and Wang, 1998; Cai et al., 1999; Neubauer and Anderson, 2003; Wang and Cai, 2004). However, due to the much broader geographic size of the Delaware Bay compared to the marine-dominated Sapelo and Doboy sounds, in-water biological processes are most likely important. In turn, the impact from the growth and decay of marsh plants on surface water $p \mathrm{CO}_{2}$ and $\mathrm{CO}_{2}$ flux dynamics may not be as influential in the Delaware Bay, except near the shorelines, where tides regularly flush marsh boundaries. Culberson et al. (1987) and Lebo et al. (1990) performed several cross-bay 
Table 3. Flushing time in five of the six zones in the Delaware Estuary during each cruise.

\begin{tabular}{|c|c|c|c|c|c|c|c|c|c|c|}
\hline & $\begin{array}{l}\text { Mar } \\
2014\end{array}$ & $\begin{array}{l}\text { Jun } \\
2013\end{array}$ & $\begin{array}{l}\text { Jul } \\
2014\end{array}$ & $\begin{array}{l}\text { Aug } \\
2013\end{array}$ & $\begin{array}{l}\text { Aug } \\
2014\end{array}$ & $\begin{array}{l}\text { Oct } \\
2013\end{array}$ & $\begin{array}{l}\text { Oct } \\
2014\end{array}$ & $\begin{array}{l}\text { Nov } \\
2013\end{array}$ & $\begin{array}{l}\text { Dec } \\
2014\end{array}$ & $\begin{array}{l}\text { Annual } \\
\text { average }\end{array}$ \\
\hline \multicolumn{11}{|l|}{ Flushing time (day) } \\
\hline Lower bay & 14.5 & 11.7 & 26.5 & 23.8 & 36.2 & 21.9 & 18.5 & 21.9 & 16.1 & 21.2 \\
\hline Mid-bay & 29.9 & 22.9 & 54.5 & 38.1 & 64.1 & 41.3 & 30.9 & 40.0 & 28.3 & 38.9 \\
\hline Upper bay & 15.1 & 13.3 & 26.6 & 23.9 & 32.8 & 25.5 & 27.6 & 27.2 & 16.6 & 23.2 \\
\hline Turbidity maximum zone & 7.6 & 7.5 & 11.9 & 13.3 & 18.5 & 19.9 & 16.1 & 16.9 & 11.3 & 13.7 \\
\hline Urban river & 2.5 & 2.3 & 3.7 & 6.1 & 6.9 & 6.5 & 6.5 & 6.5 & 5.9 & 5.2 \\
\hline
\end{tabular}

transects sampled at various depths, over diel cycles, within tributaries, and periodically offshore. Results showed that cross-bay gradients were inconsistent and relatively small, except in shallow waters near the shoreline, where total suspended sediment and chlorophyll concentrations were frequently elevated (Culberson et al., 1987; Lebo et al., 1990; Sharp et al., 2009). Thus, the impact from marsh input of DIC to the Delaware Bay on overall $p \mathrm{CO}_{2}$ distributions and associated $\mathrm{CO}_{2}$ degassing fluxes are most likely small. During December 2014, $p \mathrm{CO}_{2}$ measurements were collected not only in the main channel but also near the Delaware and New Jersey perimeters of the bay (Fig. 6i). While slight variability was observed across the bay, $p \mathrm{CO}_{2}$ values from the lower to upper bay regions remained within about $150 \mu$ atm (Fig. 6i and Table 2).

In addition to the lack of cross-bay transects, there is a pressing need to conduct more winter and early spring surveys to fully cover seasonal ranges in key properties such as temperature and river discharge rates. Moreover, cruises or moored sensor studies at or around large discharge events are needed. A recent study by Voynova and Sharp (2012) found that in the past century there have been a recorded 54 extreme discharges (defined by the average daily discharge as recorded in Trenton, NJ, from 1 October 1912 to 30 September 2011 plus 10 standard deviations), with $46 \%$ of these occurring in the past decade (Voynova and Sharp, 2012). With increasing evidence suggesting that extreme weather events will occur more frequently with climate change, it is important to maintain routine seasonal surveys to learn how such subsequent conditions (i.e., increased summer stratification, riverine $\mathrm{CO}_{2}$ fluxes, removal of oxygen in bottom waters) impact various coastal environments (Allan and Soden, 2008; Voynova and Sharp, 2012). Furthermore, more research is needed in the urban and upper river sections of the estuary to better understand $\mathrm{CO}_{2}$ dynamics throughout the whole estuarine gradient. The lack of inorganic carbon data in these upper regions limits syntheses of regional $\mathrm{CO}_{2}$ fluxes and generalizations to underlying mechanisms. Routine sampling along small tributaries and river systems could provide crucial insight into the biogeochemistry in the upper tidal river.

There are also several limitations to the temperaturenormalized and end-member mixing models that need to be addressed. First, knowing the extensively complex nature of estuarine systems, it is important to note that derived vari- ances in temperature-normalized $p \mathrm{CO}_{2}$ provide only a relatively simple analysis of seasonal $p \mathrm{CO}_{2}$ fluctuations due to thermal and non-thermal processes as it neglects the impact that various physical processes, turbulent forces, and tidal mixing scenarios have on $p \mathrm{CO}_{2}$ dynamics. However, as mentioned before, since salinity fluctuates greatly depending on factors such as season, river discharge, and tidal cycle, salinity-binned climatologies can provide crucial insight into various physical and biological controlling mechanisms behind $p \mathrm{CO}_{2}$ distributions that geographic boundaries may not. Unfortunately, due to the lack of winter surveys and unusually high $p \mathrm{CO}_{2}$ values in December, interpolated temperature-normalized $p \mathrm{CO}_{2}$ during cooler months may be biased and slightly overestimated. Moreover, the temperature-derived constants $\left(\partial \ln p \mathrm{CO}_{2} / \partial T\right)$ derived in this study were based on river and ocean end-member TA and DIC concentrations collected in the Delaware Estuary over the past 2 years. Thus, it is important to note that derived temperature constants here are applicable for general estuarine systems and may not be suitable for coastal environments with different hydrological and/or geochemical characteristics.

In situ DIC and TA measurements were coupled using the Excel macro CO2SYS (Pierrot, 2006) and inorganic carbon dissociation constants from Millero et al. (2006) for estuarine waters to calculate dissolved $\mathrm{CO}_{2}$ concentrations. While river and ocean end-members were obtained at nearzero salinity and at the mouth of the bay, respectively, no fixed end-member sampling locations were established. This marginal difference in end-member location could slightly increase or decrease estimated $\mathrm{CO}_{2}$ concentrations. In the chemical model of the $\mathrm{CO} 2 \mathrm{SYS}, \mathrm{NH}_{3}, \mathrm{NH}_{4}^{+}$, and organic matter contribution to TA were not included (Cai et al., 1998; Cai et al., 2010b), which were likely high in low-salinity waters. Thus, lower calculated than observed $\mathrm{CO}_{2}$ was expected as the observed TA included other acid-base components (Fig. 3c). However, due to the very high $p \mathrm{CO}_{2}$, such uncertainty is deemed unimportant in our consideration. Another factor that may contribute to the lower calculated than observed $\mathrm{CO}_{2}$ could be the use of mercuric chloride as a preservative in low-salinity samples $(S<10$; Trabalka and Reichle, 2013). Excess alkalinity generated via the dilution of mercuric chloride could contribute to conservative $\mathrm{CO}_{2}$ flux estimates (Trabalka and Reichle, 2013), although, due to the 
Table 4. Calculated $\Delta p \mathrm{CO}_{2 \text { thermal }}, \Delta p \mathrm{CO}_{2 \text { non-thermal }}, T-B$, and $T / B$ values for each salinity interval in the Delaware Estuary.

\begin{tabular}{|c|c|c|c|c|c|c|}
\hline & $0-5$ & $5-10$ & 10-15 & $15-20$ & $20-25$ & $25-30$ \\
\hline$\Delta p \mathrm{CO}_{2 \text { thermal }}$ ( $\mu$ atm) & 1005 & 800 & 635 & 514 & 417 & 431 \\
\hline$\Delta p \mathrm{CO}_{2 \text { non-thermal }}(\mu \mathrm{atm})$ & 773 & 477 & 615 & 635 & 604 & 473 \\
\hline$T-B(\mu \mathrm{atm})$ & 232 & 323 & 20 & -121 & -187 & -42 \\
\hline$T / B$ & 1.30 & 1.68 & 1.03 & 0.80 & 0.69 & 0.91 \\
\hline
\end{tabular}

relatively high TA in the Delaware River, we believe this effect is small.

\section{Summary and concluding remarks}

While the urban river and turbidity maximum zone are strong $\mathrm{CO}_{2}$ sources to the atmosphere, these upper regions are small in comparison to the bay regions of the Delaware Estuary. Thus, overall the Delaware Estuary acts as a relatively weak $\mathrm{CO}_{2}$ source $\left(2.4 \pm 4.8\right.$ mol- $\left.\mathrm{C} \mathrm{m}^{-2} \mathrm{yr}^{-1}\right)$ in comparison to many other estuarine systems that serve as strong $\mathrm{CO}_{2}$ sources to the atmosphere $\left(26 \pm 21 \mathrm{~mol}-\mathrm{C} \mathrm{m}^{-2} \mathrm{yr}^{-1}\right.$; Borges and Abril, 2011). Of the 62 estuaries compiled in Borges and Abril (2011), only the Aby Lagoon, a permanently stratified system, served as a sink for atmospheric $\mathrm{CO}_{2}$. Seasonal temperature cycles influence the rise and fall of surface water $p \mathrm{CO}_{2}$ throughout the Delaware Estuary, but these effects are partially compensated for by opposing cycles of biological removal and addition of $\mathrm{CO}_{2}$. Moreover, positive correlations between river-borne degassing to overall $\mathrm{CO}_{2}$ fluxes in the upper subsections of the estuary (the urban river and turbidity maximum zone) illustrate the importance of river-borne $\mathrm{CO} 2$ to overall $\mathrm{CO} 2$ degassing fluxes. Such features are typical for rapidly flushing river-dominated estuaries. While river-borne $\mathrm{CO}_{2}$ degassing fluxes heavily impact $\mathrm{CO}_{2}$ dynamics throughout the upper Delaware Estuary, these forces are largely compensated for by internal biological processes within the extensive bay system of the lower estuary.

Along the eastern Georgia (USA) coast, Jiang et al. (2008a) identified the Altamaha Sound as a riverdominated estuary with $\mathrm{CO}_{2}$ fluxes driven by river discharge. Comparably, the Kennebec Estuary, located on the central Maine (USA) coast, exhibited high river $\mathrm{CO}_{2}$ inputs and short freshwater residence times ( $\sim 4$ days), suggesting that $\mathrm{CO}_{2}$ sources in the estuary were mainly controlled by the degassing of river-borne DIC (Hunt et al., 2014). The upper Delaware Estuary showed similar results, with high river $\mathrm{CO}_{2}$ contributions and rapid freshwater transit times during all months (Fig. 10 and Table 3). In contrast, in systems with long freshwater residence times (i.e., the Delaware Bay and Scheldt Estuary), much, if not all, of the river-borne $\mathrm{CO}_{2}$ is released into the atmosphere (Abril et al., 2000; Borges et al., 2006). In turn, overall $\mathrm{CO}_{2}$ emission from the estuary is largely controlled by net community production in the mixed layer (ML NCP; Borges et al., 2006). In the case of the Euro- pean Scheldt Estuary, long freshwater residence time (30-90 days) leads to extensive DIC enrichment in the water column and high $\mathrm{CO}_{2}$ emissions to the atmosphere (Abril et al., 2000; Borges et al., 2006). Similarly, and in contrast to the rapidly flushing Altamaha Sound, Jiang et al. (2008a) identified the marsh-surrounded Sapelo Sound as a marine-dominated estuary with $\mathrm{CO}_{2}$ fluxes driven by seasonal temperature and metabolic cycles.

With its extensive geographic size, the Delaware Estuary features both a river-dominated upper estuary and an oceandominated lower bay. In this case, air-water $\mathrm{CO}_{2}$ fluxes in the heterotrophic upper estuary are significantly influenced by intense river-borne $\mathrm{CO}_{2}$ degassing akin to the riverdominated Altamaha Sound and Kennebec Estuary. The autotrophic lower estuary is governed by water-column biological processes and seasonal temperature cycles akin to the marine-dominated Sapelo Sound and Scheldt Estuary (though the Delaware Estuary and other large estuarine systems are orders of magnitude more productive than smaller marine-dominated estuaries).

The continuation of research cruises on estuarine and coastal margins can provide crucial insight into the physical and biological changes in the past, present, and future ocean systems. With such extensive surveys, collection of carbonate parameters, and comparison of carbonate parameters over time, we can significantly broaden our understanding of the processes that govern these coastal zones. In turn, such knowledge can be used to help predict and hopefully regulate the rise of current and future threats to our coastal ocean systems.

Acknowledgements. We thank the captains and crew of R/V Hugh R. Sharp and R/V Joanne Daiber for their support. We appreciate D. L. Kirchman for his supportive comments and discussion. We thank J. H. Sharp, D. L. Kirchman, G. W. Luther III, J. H. Cohen, and B. J. Campbell for sharing their research cruises and providing us the opportunity to conduct such extensive surveys. We also thank Christopher Hunt and an anonymous reviewer for their thorough and constructive reviews. The above ships of opportunity cruises were supported by awards from the National Science Foundation (OCE-1155385, OCE-1261359, and OCE-1030306) and the Delaware Sea Grant College Program (RHCE14-DESG). W.-J. Cai acknowledges UD internal funds for supporting his research.

Edited by: J. Middelburg 


\section{References}

Abril, G. and Borges, A. V.: Carbon dioxide and methane emissions from estuaries, in: Greenhouse gas emissions from natural environments and hydroelectric reservoirs: fluxes and processes, Environmental Science Series, edited by: Tremblay, A., Varfalvy, L., Roehm, C., and Garneau, M., Berlin, Heidelberg, New York, 187-207, 2004.

Abril, G., Etcheber, H., Borges, A. V., and Frankignoulle, M.: Excess atmospheric carbon dioxide transported by rivers into the Scheldt estuary, Cr. Acad. Sci. II A., 330, 761-768, 2000.

Abril, G., Commarieu, M. V., Sottolichio, A., Bretel, P., and Guérin, F.: Turbidity limits gas exchange in a large macrotidal estuary, Estuar. Coast. Shelf. S., 83, 342-348, 2009.

Allan, R. P. and Soden, B. J.: Atmospheric warming and the amplification of precipitation extremes, Science, 321, 1481-1484, 2008.

Bai, Y., Cai, W.-J., He, X., Zhai, W., Pan, D., Dai, M., and Yu, P.: A mechanistic semi-analytical method for remotely sensing sea surface $p \mathrm{CO}_{2}$ in river-dominated coastal oceans: A case study from the East China Sea, J. Geophys. Res.-Oceans., 120, 23312349, 2015.

Borges, A. V.: Do we have enough pieces of the jigsaw to integrate $\mathrm{CO}_{2}$ fluxes in the coastal ocean?, Estuaries, 28, 3-27, 2005.

Borges, A. V. and Frankignoulle, M.: Distribution of surface carbon dioxide and air-sea exchange in the upwelling system off the Galician coast, Global Biogeochem. Cy., 16, 13-1-13-13, doi:10.1029/2000GB001385, 2002.

Borges, A. V. and Abril, G.: Carbon dioxide and methane dynamics in estuaries, in: Treatise on estuarine and coastal science, edited by: Wolanski, E. and McLusky, D., Academic Press, Waltham, 119-161, 2011.

Borges, A. V., Delille, B., Schiettecatte, L.-S., Gazeau, F., Abril, G., and Frankignoulle, M.: Gas transfer velocities of $\mathrm{CO}_{2}$ in three European estuaries (Randers Fjord, Scheldt, and Thames), Limnol. Oceanogr., 49, 1630-1641, 2004.

Borges, A. V., Delille, B., and Frankignoulle, M.: Budgeting sinks and sources of $\mathrm{CO}_{2}$ in the coastal ocean: Diversity of ecosystems counts, Geophys. Res. Lett., 32, 1-4, 2005.

Borges, A. V., Schiettecatte, L.-S., Abril, G., Delille, B., and Gazeau, F.: Carbon dioxide in European coastal waters, Estuar. Coast. Shelf. S., 70, 375-387, 2006.

Cai, W.-J.: Estuarine and coastal ocean carbon paradox: $\mathrm{CO}_{2}$ sinks or sites of terrestrial carbon incineration?, Annu. Rev. Mar. Sci., 3, 123-145, 2011.

Cai, W.-J. and Wang, Y.: The chemistry, fluxes, and sources of carbon dioxide in the estuarine waters of the Satilla and Altamaha Rivers, Georgia, Limnol. Oceanogr., 43, 657-668, 1998.

Cai, W.-J., Wang, Y., and Hodson, R. E.: Acid-base properties of dissolved organic matter in the estuarine waters of Georgia, USA, Geochim. Cosmochim. Ac., 62, 473-483, 1998.

Cai, W.-J., Pomeroy, L., Moran, M. A., and Wang, Y.: Oxygen and carbon dioxide mass balance for the estuarine-intertidal marsh complex of five rivers in the southeastern US, Limnol. Oceanogr., 44, 639-649, 1999.

Cai, W.-J., Dai, M., and Wang, Y.: Air-sea exchange of carbon dioxide in ocean margins: A province-based synthesis, Geophys. Res. Lett., 33, 2-5, 2006.

Cai, W., Guo, X., Chen, A., Dai, M., Zhang, L., Zhai, W., Lohrenz, S. E., Yin, K., Harrison, P. J., and Wang, Y.: A comparative overview of weathering intensity and $\mathrm{HCO}^{-}$flux in the world's major rivers with emphasis on the Changjiang, Huanghe, Zhujiang (Pearl) and Mississippi Rivers, Cont. Shelf. Res., 28, 15381549, doi:10.1016/j.csr.2007.10.014, 2008.

Cai, W.-J., Hu, X., Huang, W.-J., Jiang, L.-Q., Wang, Y., Peng, T.H., and Zhang, X.: Alkalinity distribution in the western North Atlantic Ocean margins, J. Geophys. Res-Oceans., 115, 1-15, 2010a.

Cai, W.-J., Luther, G. W. III., Cornwell, J. C., and Giblin, A. E.: Carbon cycling and the coupling between proton and electron transfer reactions in aquatic sediments in Lake Champlain, Aquat. Geochem., 16, 421-446, 2010b.

Chen, C.-T. A. and Borges, A. V.: Reconciling opposing views on carbon cycling in the coastal ocean: Continental shelves as sinks and near-shore ecosystems as sources of atmospheric $\mathrm{CO}_{2}$, Deep-Sea. Res. Pt. II., 56, 578-590, 2009.

Chen, C.-T. A., Huang, T.-H., Chen, Y.-C., Bai, Y., He, X., and Kang, Y.: Air-sea exchanges of $\mathrm{CO}_{2}$ in the world's coastal seas, Biogeosciences, 10, 6509-6544, doi:10.5194/bg-10-6509-2013, 2013.

Cifuentes, L. A., Sharp, J. H., and Fogel, M. L.: Stable carbon and nitrogen isotope biogeochemistry in the Delaware Estuary, Limnol. Oceanogr., 33, 1102-1115, 1988.

Crosswell, J. R., Wetz, M. S., Hales, B., and Paerl, H. W.: Air-water $\mathrm{CO}_{2}$ fluxes in the microtidal Neuse River Estuary, North Carolina, J. Geophys. Res-Oceans., 117, 1-12, 2012.

Culberson, C. H.: Dissolved oxygen, inorganic carbon, and the acid-base system in the Delaware Estuary, in: Ecology and Restoration of the Delaware River Basin, Pennsylvania Academy of Science, University of Michigan, 58-76, 1988.

Culberson, C. H., Pennock, J. R., Lee, B. W., Biggs, R. B., Church, T. M., and Sharp, J. H.: Data from the YABLED cruises. September 1981- July 1984. Oceanographic data Report Number 4. Del. Sea. Grant. Program, University of Delaware, 170 pp., 1987.

Dai, T. and Wiegert, R.G.: Estimation of the primary productivity of Spartina alterniflora using a canopy model, Ecography, 19, 410423, 1996.

Dickson, A. G. and Millero, F. J.: A comparison of the equilibrium constants for the dissociation of carbonic acid in seawater media, Deep-Sea Res., 34, 1733-1743, 1987.

Dickson, A. G., Sabine, C. L., and Christian, J. R.: Guide to best practices for ocean $\mathrm{CO}_{2}$ measurements, PICES Special Publications, 3, 90-101, 2007.

Frankignoulle, M., Abril, G., Borges A.V., Bourge, I., Canon, C., Delille, B., Libert, E., and Théate, J. M.: Carbon dioxide emission from European estuaries, Science, 282, 434-436, 1998.

Gran, G.: Determination of the equivalence point in potentiometric titrations Part II, Analyst, 77, 661-671, 1952.

Huang, W.-J., Wang, Y., and Cai, W.-J.: Assessment of sample storage techniques for total alkalinity and dissolved inorganic carbon in seawater, Limnol. Oceanogr.-Meth., 10, 711-717, 2012.

Huang, W.-J., Cai, W.-J., Wang, Y., Lohrenz, S. E., and Murrell, M. C.: The carbon dioxide system on the Mississippi Riverdominated continental shelf in the northern Gulf of Mexico: 1. Distribution and air-sea $\mathrm{CO}_{2}$ flux, J. Geophys. Res-Oceans., 120, 1429-1445, 2015.

Hunt, C. W., Salisbury, J. C., Vandemark, D., and McGillis, W.: Contrasting Carbon Dioxide Inputs and Exchange in Three Adjacent New England Estuaries, Estuar. Coast, 34, 68-77, 2010. 
Hunt, C. W., Salisbury, J. E., and Vandemark, D.: $\mathrm{CO}_{2}$ input dynamics and air-sea exchange in a large New England estuary, Estuar. Coast, 37, 1078-1091, 2014.

Jiang, L.-Q., Cai, W.-J., and Wang, Y.: A comparative study of carbon dioxide degassing in river- and marine-dominated estuaries, Limnol. Oceanogr., 53, 2603-2615, 2008a.

Jiang, L.-Q., Cai, W.-J., Wanninkhof, R., Wang, Y., and Lüger, H.: Air-sea $\mathrm{CO}_{2}$ fluxes on the US South Atlantic Bight: spatial and seasonal variability, J. Geophys. Res., 113, C07019, doi:10.1029/2007JC004366, 2008b.

Ketchum, B. H.: The distribution of salinity in the estuary of the Delaware River, Woods Hole Oceanographic Institution, Woods Hole, Massachusetts, 1952.

Laruelle, G. G., Lauerwald, R., Rotschi, J., Raymond, P. A., Hartmann, J., and Regnier, P.: Seasonal response of air-water $\mathrm{CO}_{2}$ exchange along the land-ocean aquatic continuum of the northeast North American coast, Biogeosciences, 12, 1447-1458, doi:10.5194/bg-12-1447-2015, 2015.

Lebo, M. L., Cifuentes, L. A., Fogel, M. L., Hoch, M. P., Keil, R. G., Kirchman, D. L., Ludlam, J. M., Pennock, J. R., Sharp, J. H., Spicer, P. T., and Velinsky, D. J.: Data from the Delaware Estuary Scenic Cruises, April 1986-September 1988, Oceanographic Data Report Number 7, Del. Sea. Grant. Program, University of Delaware, 139 pp., 1990.

Mehrbach, C., Culberson, C. H., Hawley, J. E., and Pytkowicz, R. M.: Measurement of the apparent dissociation constants of carbonic acid in seawater at atmospheric pressure, Limnol. Oceanogr., 18, 897-907, 1973.

Millero, F. J., Graham, T. B., Huang, F., Bustos-Serrano, H., and Pierrot, D.: Dissociation constants of carbonic acid in seawater as a function of salinity and temperature, Mar. Chem., 100, 8094, 2006.

McGillis, W. R., Edson, J. B., Hare, J. E., and Fairall, C. W.: Direct covariance air-sea $\mathrm{CO}_{2}$ fluxes, J. Geophys. Res-Oceans., 106, 16729-16745, 2001.

McGillis, W. R., Edson, J. B., Zappa, C. J., Ware, J. D., McKenna, S. P., Terray, E. A., Hare, J. E., Fairall, C. W., Drennan, W., Donelan, M., DeGrandpre, M. D., Wanninkhof, R., and Feely, R. A.: Air-sea $\mathrm{CO}_{2}$ exchange in the equatorial Pacific, J. Geophys. Res-Oceans., 109, 1978-2012, 2004.

Neubauer, S. and Anderson, I. C.: Transport of dissolved inorganic carbon from a tidal freshwater marsh to the York River estuary, Limnol. Oceanogr., 48, 299-307, 2003.

Pennock, J. R. and Sharp, J. H.: Temporal alternation between light and nutrient-limitation of phytoplankton production in a coastal plain estuary, Mar. Ecol.-Prog. Ser., 111, 275-288, 1994.

Pierrot, D., Lewis, E., and Wallace, D. W. R.: CO2SYS DOS Program Developed for CO2System Calculations. ORNL/CDIAC105, Carbon Dioxide Information Analysis Center, Oak Ridge National Laboratory, US Department of Energy, Oak Ridge, California, 2006.

Raymond, P. A. and Cole, J. J.: Gas exchange in rivers and estuaries: choosing a gas transfer velocity, Estuaries, 24, 312-317, 2001.

Raymond, P. A., Caraco, N. F., and Cole, J. J.: Carbon dioxide concentration and atmospheric flux in the Hudson River, Estuaries, 20, 381-390, 1997.

Raymond, P. A., Bauer, J. E., and Cole, J. J.: Atmospheric $\mathrm{CO}_{2}$ evasion, dissolved inorganic carbon production, and net heterotro- phy in the York River estuary, Limnol. Oceanogr., 45, 17071717, 2000.

Regnier, P., Friedlingstein, P., Ciais, P., Mackenzie, F. T., Gruber, N., Janssens, I. A., Laruelle, G. G., Lauerwald, R., Luyssaert, S., Andersson, A. J., Arndt, S., Arnosti, C., Borges, A. V., Dale, A. W., Gallego-Sala, A., Godderis, Y., Goossens, N., Hartmann, J., Heinze, C., Ilyina, T., Joos, F., LaRowe, D. E., Leifeld, J., Meysman, F. J. R., Munhoven, G., Raymond, P. A., Spahni, R., Suntharalingam, P., and Thullner, M.: Anthropogenic perturbation of the carbon fluxes from land to ocean, Nat. Geosci., 6, 597-607, doi:10.1038/ngeo1830, 2013.

Salisbury, J. E., Vandemark, D., Hunt, C. W., Campbell, J. W., McGillis, W. R., and McDowell, W. H.: Seasonal observations of surface waters in two Gulf of Maine estuary-plume systems: Relationships between watershed attributes, optical measurements and surface $p \mathrm{CO}_{2}$, Estuar. Coast. Shelf. S., 77, 245-252, 2008.

Sharp, J. H.: The Delaware Estuary: Research as background for estuarine management and development, Univ. Delaware Sea Grant College Program, 79-118, 1983.

Sharp, J. H.: Estuarine oxygen dynamics: What can we learn about hypoxia from long-time records in the Delaware Estuary?, Limnol. Oceanogr., 55, 535-548, 2010.

Sharp, J. H., Yoshiyama, K., Parker, A. E., Schwartz, M. C., Curless, S. E., Beauregard, A. Y., Ossolinski, J. E., and Davis, A. R.: A biogeochemical view of estuarine eutrophication: seasonal and spatial trends and correlations in the Delaware Estuary, Estuar. Coast, 32, 1023-1043, 2009.

Sheldon, J. E. and Merryl, A.: A comparison of residence time calculations using simple compartment models of the Altamaha River Estuary, Georgia, Estuaries, 25, 1304-1317, 2002.

Takahashi, T., Ólafsson, J., Goddard, J. G., Chipman, D. W., and Sutherland, S. C.: Seasonal variation of $\mathrm{CO}_{2}$ and nutrient salts over the high latitude oceans: A comparative study, Global Biogeochem. Cy., 7, 843-878, 1993.

Takahashi, T., Sutherland, S. C., Sweeney, C., Poisson, A., Metzl, N., Tilbrook, T., Bates, N., Wanninkhof, R., Feely, R. A., Sabine, C., Olafsson, J., and Nojiri, Y.: Global sea-air $\mathrm{CO}_{2}$ flux based on climatological surface ocean $p \mathrm{CO}_{2}$, and seasonal biological and temperature effects, Deep-Sea Res. Pt. II, 49, 1601-1622, 2002.

Trabalka, J. R. and Reichle, D. E.: The changing carbon cycle: A global analysis, Springer, New York, 2013.

Voynova, Y. G. and Sharp, J. H.: Anomalous biogeochemical response to a flooding event in the Delaware Estuary: a possible typology shift due to climate change, Estuar. Coast, 35, 943-958, 2012.

Wang, Z. A. and Cai, W.-J.: Carbon dioxide degassing and inorganic carbon export from a marsh-dominated estuary (the Duplin River): A marsh $\mathrm{CO}_{2}$ pump, Limnol. Oceanogr., 49, 341-354, 2004.

Wanninkhof, R.: Relationship between wind speed and gas exchange over the ocean, J. Geophys. Res-Ocean., 97, 7373-7382, doi:10.1029/92jc00188, 1992.

Wanninkhof, R.: Relationship between wind speed and gas exchange over the ocean revisited, Limnol. Oceanogr-Meth., 12, 351-362, 2014.

Wanninkhof, R., Doney, S. C., Takahashi, T., and McGillis, W. R.: The effect of using time-averaged winds on regional air-sea $\mathrm{CO}_{2}$ fluxes, in: Gas transfer at water surfaces. Geophysical Mono- 
graph Series, edited by: Donelan, M., Drennan, W., Saltzman, E., and Wanninkhor, R., AGU, Washington D.C., 351-357, 2002.

Wanninkhof, R., Asher, W. E., Ho, D. T., Sweeney, C., and McGillis, W. R.: Advances in quantifying air-sea gas exchange and environmental forcing, Ann. Rev. Mar. Sci., 1, 213-244, 2009.

Weiss, R. F.: Carbon dioxide in water and seawater: the solubility of non-ideal gas, Mar. Chem., 2, 221-231, 1974.

Yoshiyama, K. and Sharp, H. J.: Phytoplankton response to nutrient enrichment in an urbanized estuary: Apparent inhibition of primary production by overeutrophication, Limnol. Oceanogr., 51, 424-434, 2006.
Zappa, C. J., McGillis, W. R., Raymond, P, A., Edson, J. B., Hintsa, E. J., Zemmelink, H. J., Dacey, J. W. H., and Ho, D. T.: Environmental turbulent mixing controls on air-water gas exchange in marine and aquatic systems, Geophys. Res. Lett., 34, L10601, doi:10.1029/2006GL028790, 2007. 